\begin{tabular}{c} 
International Journal of Scientific World, $5(2)(2017) 177-192$ \\
International Journal of Scientific World \\
SPC \\
Website: $\begin{array}{c}\text { www. sciencepubco.com/index.php/IJSW } \\
\text { doi: } 10.14419 / i j s w . v 5 i 2.8351 \\
\text { Research paper }\end{array}$ \\
\hline
\end{tabular}

\title{
A critical review of production factors that influence egg quality traits
}

\author{
John-Jaja Sylvia Alwell ${ }^{1}$, Abdullah Abdur-Rahman ${ }^{1}$, Nwokolo Samuel Chukwujindu ${ }^{2}$ * \\ ${ }^{I}$ Department of Animal Science, College of Agriculture, Babcock University, Ilshan Remo, Nigeria \\ 2 Department of Physics, Faculty of Physical Sciences, University of Calabar, Calabar, Nigeria \\ *Corresponding author E-mail: nwokolosc@ stud.unical.edu.ng
}

\begin{abstract}
The global poultry industry has experienced significant changes in the methods used to harvest and process the fresh egg over the past century. Applications of animal genetics and breeding have significantly increased in line speed for poultry operation. In this study aims at reviewing production factors that influence egg quality traits across the globe. The production factors so far utilized were classified into three main categories and presented based on their influencing capacity. For this purpose, two types of search criteria to find publications relevant to the scope of this review were employed. The first type was an automatic search performed on the following publishers' databases: ScienceDirect, Google's scholar, researcher gates, academia. The second type was a manual search on conferences, recent theses and dissertation that have not been published in journals from numerous Babcock University. Generally, 23 publications were reported for the breed; 17 for housing, and 19 for age of the breed after excluding studies that do not focus explicitly on breed, housing and age of the bird as production factors that influenced egg quality traits out of 183 potential relevant articles identified from January 2001 to December 2016. Thus, this review would provide animal genetics and breeding researchers in terms of identifying the most potent breed, adequate housing system and precise age for optimum production of birds with high quality.
\end{abstract}

Keywords: Critical Review; Egg Quality Traits; Breed; Housing Systems; Age of Birds.

\section{Introduction}

Poultry raised for meat and eggs are important sources of edible animal protein. Poultry meat account for $30 \%$ of global meat consumption. The world-wide average per capital consumption of poultry meat has nearly quadrupled since the 1960's FAO [1]. This transformation could be due to the wide spread of the necessity of animal protein intake per day per individual, considering production factors that influence poultry parameters such as breed housing, feeding, management system, disease control, temperature difference and age etc. of internal and external parameters of poultry birds (local and exotic) hen thereby improving both the meat quality and egg quality parameters.

Egg quality traits are those that influence its acceptability by consumers. Hence, to maintain the superiority in the total egg quality, routine genetic and breeding experimentation considering the production factors such as breed, housing and age that primarily influence egg quality parameters should be carried out continuously for a number of chicken traits in both local, exotic and even crossbred birds.

For global commercial egg production, it is estimated that over $75 \%$ of hen are reared in cages but new trends are emerging in rearing layers in animal-friendly systems [2]. However, production factors are important for egg production cost, number of salable and its quality gain importance. Thus, studies have been conducted under the influence of different housing systems, such as conventional-cage, enriched cage, and outdoor systems, aviary, cage density, cage in different tiers deep litter, free-range on external and internal egg quality parameters [3-12].
The breed is one of the most important production factors affecting egg quality parameters. Careful selection of breed type is important for producers in order to produce egg with high quality and low cost. Hence, studies have been investigated on the impact of different breed on external and internal egg quality parameters [8], [13-18].

The age of hen is another of the production factors that affect egg quality characteristics. Since the last 20 years, genetic improvement of layers has allowed producers to extend the egg production cycle from 68 weeks to 80 or even 90 weeks of age [19]. Increasing the production period of hens without moulting has both financial and environmental implications. In a longer laying cycle, the cost of egg production such as pullet purchase price and feed are balanced by the earnings of a longer productive period. Besides, replacements of hens, depopulation and cleaning of the poultry unit are less often needed which all mean reduced costs and reduced amount of resources required in the long term [20]. However, a profitable extended laying cycle can only be achieved if persistency and egg quality are maintained throughout the last phase of the production duration. As a result of high variation in clutch length between hens, laying rate starts declining after two weeks of age [20-22]. This is followed by deterioration in egg quality, not only internal but also shell quality decreased, which is likely to result in breakage during collection and transport. This will at a certain point lead to breakage in such losses that it is not economical any longer to produce with the stock [22]. Hence, studies have been conducted on the effects of age on external and internal egg quality traits [2], [17], [23-28].

Of course, there are many review relating to production factors that affect egg quality traits [29-33], but the focus of this review 
was to present current understanding of production factors (breed, housing and age) influencing egg quality traits.

\section{Materials and methods}

To advance our understanding on production factors that affect egg quality traits, the present study consisted of a systematic literature review with specific focus on research related to influence of breed, housing and age on egg quality parameters. A systematic review differs from a traditional general review as it adopts a replicable, scientific and transparent process. The purpose of a systematic review of literature is three-fold:

1) To present a fair evaluation of a research topic by a rigorous and systematic method.
2) To help in identifying any gaps in the current research in order to suggest further improvements; and

3) To summarize and provide background for new research activities.

This culminates into developing collective insights based on theoretical synthesis of existing studies. Previous researchers have argued that using such an approach to review literature can ensure that bias (i.e. systematic error) is limited; chance effects are reduced, and the legitimacy of data analysis is enhanced. The design of the systematic review reported in this study stated in March 2017. After several refinements and improvements, publication search was started April 2017. Figure 1 presents the search method that was adopted for systematic review.

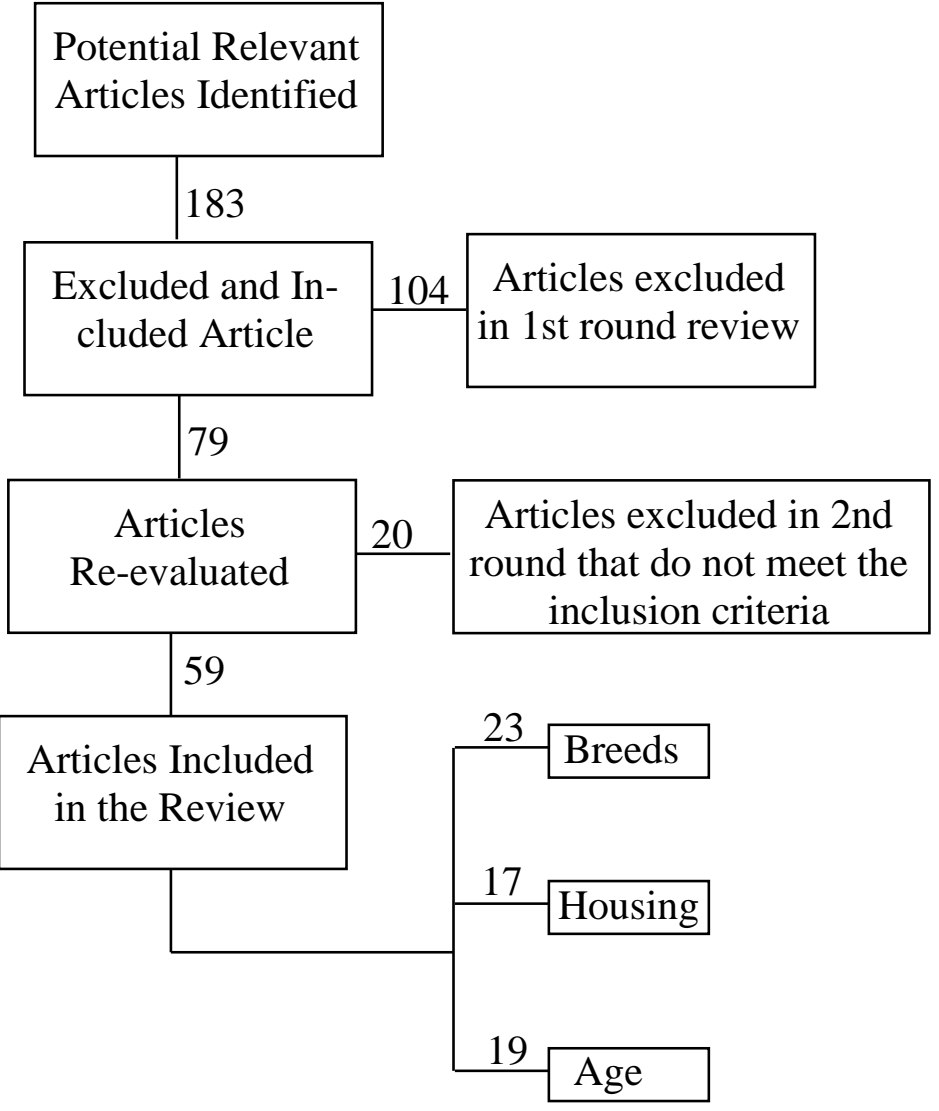

Fig. 1: Systematics Review Flow Diagram.

\subsection{Planning the review}

This research is planned by proposing research questions relevant to the research objectives. The following steps present the data sources, search strategies, the publication selection and screening criteria.

\subsubsection{Review objective and research questions}

With the increased use of animal breeding and genetics and production of edible chicken for commercial purposes, it has become necessary to study the production factors influencing egg quality traits which are the major criteria for its acceptability to the consumers. Therefore, the goal of this study is to develop an understanding of production factors that influence egg quality parameters.

Since research questions guide the design of any systematic review. To fulfil these objectives, the research questions are formulated as follows:
1) RQ: Which production factors that affect egg quality parameters are being addressed by researchers and how are studies distributed across these techniques?

As current strategies and knowledge on production factors that affect egg quality traits is dispersed across many papers, the work will be employed as a way to structure the analysis of the body of knowledge on a single work sheet. This will enable us to determine which production factor get the most/least influence and can be most adventitious.

2) RQ: How effective are breed, housing and age affected production factors processes?

The aim of this second research question is to assess the current influence of breed, housing and age on egg production processes over other production factors such as handling/collecting eggs, disease control and management etc. The current review will help breeders and egg producers to know situation production factors that can boost egg quality traits for the teaming population of the globe. 


\subsubsection{Search strategy}

After defining the research goals and questions, the researchers started with the formulation of a formal search strategy to analyze all available literature materials specific to the objective of this review. The plan involved defining the search space, which in cluded electronic databases as presented in Table 1. This study performed two types of search to find publications relevant to the scope of the review. The first type was an automatic search performed on the following publishers' databases: ScienceDirect, Google's scholar, researcher gates, academia. The second type was a manual search on conferences, recent theses and dissertation that have not been published in journals from Babcock University Library. The manual search was made based on the researchers' collective observations during the pilot searches. This supplementary strategy aimed to add any potential works that might have been left out during the search processes.

Table 1: Search Sources

\begin{tabular}{ll}
\hline Table 1: & Search Sources \\
\hline ScienceDirect \\
SpringerLink \\
Wiley \\
Google Scholar \\
Researchgates \\
Academia
\end{tabular}

\subsubsection{Search criteria}

The search criterion employed for this review is defined as follows. The first step begins by setting certain practical screening criteria to ensure that only quality publications are included in the review. During the first search, therefore, conference articles, thesis and dissertations were excluded, aiming instead for a focus on journal publication. This delimitation also secured the focus on quality publication related to production factors that affect egg quality traits and related concepts. No other quality criteria were used (e.g. journal rankings) for filtering; indeed. The search also excluded articles that were not peer-reviewed or not written in English language. A number of pilot searches were performed to refine the keywords in the search string using trial and error. The terms whose inclusion did not yield additional articles in the automatic searches are removed.

\subsubsection{Inclusion and exclusion criteria}

The purpose of the present study is to focus on production factors (such as breed, housing and age) that affects quality traits; only articles that discussed breed, housing and age factors that affect egg, quality traits were included. More specifically, the inclusion criteria for articles selected for full review were as follows: Inclusion Criteria:

1) Studies that discussed influence of numerous breeds or crossbreed or comparison of different breed on egg quality traits were included.

2) Studies that discussed effects of various housing on egg quality traits were included.

3) Studies that discussed impacts of age variance on egg quality traits were included.

Exclusion Criteria:
1) Studies that do not focus explicitly on production factors that affect egg quality traits, but only refer to effect of production factors on egg quality as a side work.

2) Studies that do not discuss breed, housing and age as production factors that egg quality traits.

3) Studies that do not meet inclusion criteria.

Based on the criteria evaluation, each publication was either included or excluded. In cases where the researchers view on the abstract screening differed, the researchers scanned the entire article for relevance. This time-consuming process resulted in including 59 articles out of 183 that were included after the inclusion criteria as presented in Table 2 .

Table 2: Search Result and Fitted Articles According to Search Terminology

\begin{tabular}{llllll}
\hline \multirow{2}{*}{ Databases } & Retrieved & Round 1 & \multicolumn{3}{c}{ Round 2 } \\
\cline { 3 - 6 } & & Included & Excluded & Included & Excluded \\
\hline ScienceDirect & 28 & 4 & 24 & 4 & 0 \\
SpringerLink & 4 & 3 & 1 & 3 & 0 \\
Wiley & 8 & 2 & 6 & 2 & 0 \\
Google Scholar & 130 & 67 & 63 & 47 & 20 \\
Researchgates & 11 & 2 & 9 & 2 & 0 \\
Academia & 2 & 1 & 1 & 1 & 0 \\
Total & 183 & 79 & 104 & 59 & 20 \\
\hline
\end{tabular}

\subsubsection{Data extraction}

The data extraction process is defined to identify important information from the 59 included primary studies that are related to the research questions. The data extraction process includes the following: the authors set up a form to record ideas, concepts, contributions and findings of each of the 59 studies. Employing this form ensures subsequent higher-order interpretation. The following data were extracted from each publication: title, authors, reference, databases, relevance to the theme, i.e. influence of breed, age and housing on egg quality traits and year of publication.

\section{Influence of production factors on egg qual- ity traits}

Maintaining fresh egg quality from producer to consumer is one of the major challenges facing those engaged in marketing eggs. Proper attention to production procedures, distribution and point of scale phases are the major importance in maintaining egg quality. The main production factors that influence egg quality maintenance are but not limited to the following:

\subsection{Breed}

As a result of general selection, different strains or breed hen may significantly differ in egg quality, egg size and production and there is significant difference between the genetically modified breeds and traditional breeds (unmodified breed) of laying fowl. Animal breeding and genetics for one breed can alter other characteristics of the hen such as egg quality traits, which constitute a significant portion of the egg quality available in the market. The breed of the laying hen influences shell colour; for example, leghorn produce white eggs, while Rhode Island Red produces brown eggs. The following egg quality factors are poultry inherited: shell texture and thickness, the incidence of blood spots and the upstanding quality and relative amount of thick albumen. However, it may not always be possible; a constituent policy of selection for breeds by egg producers can bring observable improvements to quality. The results of the experiments on the potential influence of breed on egg quality traits are summarized in Table 3 .

Sreenivas et al. [14] investigated genetic analysis of different strains of white leghorn chicken on egg quality traits for forty weeks in India. Significant differences $(p<0.001)$ were observed among the three strains and control population with respect to 
various egg quality traits. Similar differences were reported by other researchers for white leghorn in India [34-39].

Blance et al. [16] employed two breeding programmes: white egg lines (67 - 70 weeks of age) and brown egg lines (32 - 36 weeks of age) to determine genetic parameters of egg quality traits on different pedigree layers with special focus on dynamic stiffness. The line (male and female) within each breeding program showed a significant effect on all measured egg quality traits such as egg weight, breaking strength, dynamic stiffness, shell thickness, shape index and albumen height. Breeds and lines of the same strain differ in reproductive traits and Curtis et al. [40] found that different strains of laying hens show different eggshell quality, egg size and level of production.

Tadesse et al. [15] applied different production systems to quantify the influence of different breeds on egg quality traits of exotic chickens. The data collected was analyzed employing SPSS, and the significant differences in egg quality traits were compared using post hoc multiple comparisons. Mean egg weight, haugh unit, shell thickness, yolk colour, albumen weight, yolk percent and yolk to albumen ratio of Isa Brown (IB) showed a significant difference $(\mathrm{P}<0.05)$ under intensive and village production systems. Bovan Brown (BB) showed a statistical significant difference $(\mathrm{P}<0.05)$ for egg weight, yolk height, albumen height, yolk colour, haugh unit, shell thickness, yolk percent and albumen percent under intensive and village production systems. The study revealed that even though the differences were observed in egg quality traits under intensive and village systems, eggs produced from the village were also found to be good quality.

Khalil et al. [13] used genetic experiment to determine the influence of breed difference on Egyptian strain of Golden Mountain (M) and a foreign breed of white Leghorn (L). Results showed that eggs of crossbreeds were generally better in egg quality traits than eggs in purebreds. Eggs of L breed were significantly better than $M$ strain in most traits $(P<0.05)$, while eggs of $M$ strain were better in Haugh Unit (HU), Egg Shape Index (ESI) and Shell Thickness (ST) compared to eggs of L breed.

Musa et al. [41] applied genetic analysis of two commercial layer breeds (White Leghorn and Rhode Island Red) at 72 weeks of age to determine the effect of the breeds on the egg quality traits such as egg weight, shape index, breaking strength, shell thickness, specific gravity, albumen height, albumen index, yolk height, haugh unit and yolk colour. The result showed that the two commercial layer genotypes were significant at $(\mathrm{P}<0.05)$ for all the traits.

Islam and Dulta [42] employed genetic group to determine the influence of the breed on quality traits in Rajshashi, Baugludesh. The result showed that highly significant differences exist for both internal and external egg quality traits between the genetic groups of chicken $(\mathrm{P}<0.01)$. Even though Rhode Islam Read (RIR) showed the highest egg weight and Egg Volume (EV) and Fayoumi had the lowest for both traits, Albumen Ratio (AR) was in the sequence of cobb $500>$ RIR > Fayoumi > Sonali.

Lukanov et al. [43] used shell colour characteristics of crosses between Araucana and Schijindelaar to evaluate the influence of highly productive white leghorn and Rhode Islam Red strains on the egg quality traits. It was reported that the egg quality trait in white leghorns $(\mathrm{P}<0.001 ; \mathrm{P}<0.05)$ is more significant compared to Rhode Islam Red breed $(\mathrm{P}<0.001 ; 0.01 ; 0.05)$.

Tadesse et al. [44] applied village production system to study the influence of productive performances of different breeds of exotic chickens on egg quality traits in East Shewa, Ethiopia. The authors recorded that the strain Bovan Brown (BB) was significantly $(\mathrm{P}<$ 0.05) superior for egg weight, yolk height, albumen height, albumen weight, haugh unit and eggshell thickness than Isa Brown (IB) and pot chefs from Koekoek (PK). The IB was found to be significantly $(\mathrm{P}<0.05)$ superior to $\mathrm{BB}$ and $\mathrm{PK}$ for yolk Weight. The authors concluded that the egg quality traits obtained from these layers was a good quality at village level. Whereas PK was significantly superior to IB and BB for yolk colour.

Ewa et al. [18] employed four inbred line chicken strains to evaluate the effect of breed on the egg quality traits. No difference $(\mathrm{P}<$
0.05) were found in all traits (Egg weight, egg length, egg breadth, egg shape index, shell weight and shell thickness) measured within the same strain with regard to exotics (Black Olympia (ESA) and $\mathrm{H} \& \mathrm{~N}$ Brown Nick (ESB) and locals (Local Type A (LTD), and Local Type B, LTB). Much discrepancy $(\mathrm{P}<0.05)$ in the egg biometrical measurement occurred between the exotic strains and local types. However, there was no significant $(\mathrm{P}<0.05)$ differences in ESI of eggs from the exotic strains and local types.

Tumova et al. [45] applied genetic interaction to ascertain the impact of genotype in relation to internal and external egg quality traits in Brown laying strains ISA Brown, Hisex Brown, Bovans Brown and Moravia BSL for over 60 weeks. In experiment 1, egg weight, egg shell and egg thickness were not significant $(\mathrm{P}<0.05)$ whereas, yolk weight, yolk colour, albumen weight, haugh units, yolk/albumen ratio, egg shell strength, egg shell surface, egg shell colour and egg shell index were found to be highly significant $(\mathrm{P}$ $<0.05)$ employing two housing system - cage and litter. All the traits were found to be significant $(\mathrm{P}<0.05)$ in experiment 2 involving three housing system - cage, litter and enriched cages. The researchers concluded that the egg shell quality indicators were highly affected by genotype compared to housing system.

In an experiment to determine the influence of genotype on egg quality traits, Zita et al. [17] observed that Hisex Brown and Isa Brown recorded a significant $(\mathrm{P}<0.001)$ higher egg weight $(55.0$ vs 54.0g) than the Moravia BSL (51.1g) at the beginning of the experiment, but at the end of the experiment Moravia BSL produced the heaviest eggs $(65.3 \mathrm{~g})$. The researchers concluded that highest egg weight and yolk weight were found in Moravia BSL at the end of the experiment. Conversely, the best albumen quality values were found in Hisex Brown. In addition, the eggshell quality measurements were higher in Isa Brown. The highest deviation in egg weight during the experiment was in Moravia BSL.

In a study to evaluate effects of Lohmann white and Czech hen housed in cages and litter on egg quality parameters. Ketta and Tumova [11] revealed that egg weight in Lohmann white was highly significant $(\mathrm{P}<0.05)$ compared to that in Czech hen. They opined that the results indicated that genotypes can have a different reaction in the eggshell quality depending on housing system, and these interactions can be more important than individual factors.

Suobodova et al. [46] studied the effects of genotype using two housing system, cage and litter on egg quality traits such as egg weight, shape index, egg shell weight, albumen weight, albumen index, haugh unit, yolk weight, yolk index and yolk colour. The result revealed that egg weight, haugh unit, yolk weight, yolk index and yolk colour were not significant $(\mathrm{P}<0.001)$, whereas shape index, eggshell, albumen weight, albumen index and yolk share were highly significant $(\mathrm{P}<0.001)$. The experiment finally revealed that yolk index, and yolk colour were higher in eggs from Czech hen compared to yolk weight.

Tumova et al. [7] employed genotypes (Czech hen and Lohmann) in order to determine their influence on egg quality traits. The results indicated that all production parameters for Czech hen were lower compared with Lohmann $(\mathrm{P}<0.001)$. Egg shell parameters for weight, percentage, thickness, strength and density were higher $(\mathrm{P}<0.001)$ in egg laid by the Lohmann hens. In all, the results of the study show that genotype resulted in large differences in measurements of egg weight and eggshell quality.

In a research to determine the effect of genotype, housing system and egg collection time on egg quality traits, Tumova et al. [47] used genotype such as Isa Brown, Hisex Brown and Morava housed in cage, and on litters to genetically evaluate its effects on the egg quality parameters such as egg weight, egg index, albumen weight, haugh units, albumen index, yolk weight, yolk index and yolk colour. The result of the experiment showed that genotype influenced the all the egg quality traits $(\mathrm{P}<0.001)$. The highest egg weight $(62.09 \mathrm{~g})$ was recorded in Hisex Brown genotype placed in cage and at 06.00. Egg shell was lower in the Moravia genotype in comparison with the other two strains.

Bozkurt et al. [48] employed four genotypes (Lohman Brown, Isa Brown, Lohman white, Bovan white) in order to determine the 
level of influence it posits on body weight average. The result shown that the body weight average was affected significantly by the genotype $(\mathrm{P}<0.01)$. Brown egg layer genotypes were lighter, more uniform and gained more weight with less feed. White egg layers were more sensitive to the effects to treatment.

Singh et al. [8] employed four strains of laying hens kept in conventional cages and floor pens to assess the level of impact on the egg quality traits. The result revealed that the albumen height of Brown egg layers in cages was not different between week 30 and 40 , and that for white egg layers was not different between week 40 and 50. In floor pens, only $\mathrm{H} \& \mathrm{~N}$ white eggs differed significantly $(\mathrm{P}<0.05)$ between week 20 and 30 and had the lowest albumen height at week 20 (based on only 9 eggs). Albumen height for all strains decreased as the age increased in both environments. For white egg layers, there has no difference in yolk colour between week 40 and 50, whereas for Brown egg strains the difference between these eggs was significant $(\mathrm{P}<0.05)$. Conversely, in floor pens, eggs from Brown egg layers and $\mathrm{H} \& \mathrm{~N}$ white hens recorded greater yolk colour at week 40 and 50 than at week 20 and 30. However, Lohmann white hens reported significantly $(\mathrm{P}<0.05)$ lower yolk colour at week 50 than at week 40 and the lowest colour at week 20 and 30 . The authors suggested that genotype should be considered when alternative housing systems are proposed for determining the performance of egg quality parameters.

Vits et al. [49] employed two laying hen strains of Lohmann Selected Leghorn (LSL) and Lohmann Brown (LB) so as to determine their corresponding effect on egg quality trait. There were significant difference between $(\mathrm{P}<0.05)$ the two layer lines. Egg weight of Brown LB layer line was higher than that of the white LSL layer line. However, Haugh units and shell thickness of Lohmann Selected Leghorn (LSL) layer line were significantly higher $(\mathrm{P}<0.05)$ compared to Brown LB layer line. Thus, the result revealed that egg quality traits were highly influenced by the breeds.

Goto et al. [50] used Onagudori (Japanese extremely long tail) and white leghorn breeds to ascertain their respective influence on egg quality traits. The ANOVA result revealed that the Onagador showed a significantly $(\mathrm{P}<0.01)$ lower egg weight, egg length, and egg breadth in the Onagadori than those of the white leghorn The egg shell weight (ESW) and egg shell strength of the Onagadori were significantly $(\mathrm{P}<0.01)$ lower compared to white leghorn respectively. Egg shell thickness were comparable between the two breeds. The Onagadori showed significantly lower value of the albumen weight than those of the white leghorn $(\mathrm{P}<0.01)$. Khawaja et al. [51] employed Fayoumi, Rhode Island Red (RIR), reciprocal crossbred chickens during brooding and growing periods (up to 20 weeks) in order to improve the breeds. The egg weight was highest in Rhode Island Red (RIR) and Fayoumi male $x$ RIR female: FIRI (FIRI), intermediate in RIR male x Fayoumi female (RIFI) and lower in Fayoumi. The results are in line with findings of Favooq et al. [52], who reporter higher egg weight in RIR and lower in Fayoumi chickens.

Somu [53] studied Girivoya and Desi birds under backyard system in order to determine the breed with superior egg quality traits. The author discovered that the mean egg weight of first lay and mean weight of Girivoja birds was significant $(\mathrm{P}<0.05)$ higher compared to Desi birds. This is comparable to the report of several researchers on the same breed [54-56].

Tadesse et al. [57] evaluated the egg production performance in Bovan Brown (BB) and KocKock (KK) chicken breeds in order to study the effect of breed on the egg quality parameters. The result revealed significantly $(\mathrm{P}<0.05)$ higher compared to Total Collected Eggs (TCE) in KK and average egg weight in BB breed. There was no significant difference in Egg Mass (EM) among all main and interaction effects. The authors also revealed that KK chicken are well adapted to semi-arid conditions in Ethiopia and their production performance was better than the $\mathrm{BB}$ chicken indicating that it is a good choice for egg producers who can regularly supply supplementary feed. Besides farmers may opt for the KK breed because of their lower mortality, plumage colour and overall confirmation.

Alew and Melesse [58] evaluated the growth performance of local Kei chickens and their $\mathrm{F}_{1}$ - crosses with Rhode Islam Red (RIR) and Fayoumi breeds in watershed areas of Ethiopia in order to improve the breeds. The result revealed that the highest body weight observed in $F_{1}$ - crosses at hatch suggests that crossing of local Kei chickens with RIR and Fayoumi breeds has significantly $(\mathrm{P}<0.05)$ improved the body weight at hatch. Similarly, an improvement in body weight at hatch of indigenous chickens at hatch in Northwest Ethiopia reported by Hassen [59] was 27.2g for Tilili, 27.9g for Gelila, 27.1g for D/Elias and 27.9g for Mecha under intensive management, which was comparable with the current findings.

Taha and AbdEl-Ghany [60] employed crossbreeding to improve El-Salam (SS) and Mandarah chicken (MM) and hence determine their effect on strains. The result revealed that El-salami x Mandarah (SM) cross showed superiority of Body Weight (BW) with positive heterosis percentages; while negative heterosis percentages were recorded for Mandonah x El-salam (MS) cross. Also, SM cross reported the highest daily weight gain at 4, 12 and 16 weeks of age with high positive heterosis percentages up to 16 weeks of age, high overall Relative Growth Rate (RGR) from 0 8 and $0-12$ weeks of age with corresponding heterosis percentages $(0.46$ and $0.73 \%)$. Similarly, SM and SS line showed the highest significant differences for Shank Length (SL) and Keel Length (KL) at 4, 8 and 12 weeks of age with positive heterosis percentages for SM line, but no effect for crossing percent on Body Circumferences (BC). The authors concluded that, using Elsalam strain as a sire line and Mandarah strain as a dam line resulted in SM cross of improved growth performance traits. The egg weight in the Onagadori showed significantly lower values than those of the white leghorn. There were no significant differences between the two breeds in the egg yolk colours.

Oyeagu et al. [61] applied New Black and Shaver Brown lines to determine their individual influence on the egg quality traits. The result revealed that no significant differences $(\mathrm{P}<0.05)$ between the two breeds were recorded for egg shell thickness, egg shell weight, egg length and egg shape index.

Toye et al. [62] used Black Harco and Lohmann Brown layers to evaluate the effects of breed on egg quality traits. The result reported that Harco black was significantly $(0.05)$ lower compared to Lohmann Brown counterpart in all the traits such as egg weight, egg length, egg breadth and egg shape index measured.

Tadesse et al. [44] employed Isa Brown (IB), Bovan Brown (BB) and Potchefstroom Koekoek $(\mathrm{PK})$ to determine productive performances and egg quality traits of exotic chickens under village production system. The authors revealed that hybrid layers lack self-replacing ability at village level due to their low mothering ability and broodiness and higher demand for exotic chickens by farmers to rear under improved village production system. This result is comparable to the findings of Tixier-Boichard et al. [63] using commercial Brown egg layer and a local breed, the Fayoumi.

Yakubu et al. [64] showed that Lohmann Brown was superior to Bovans Brown in body weight. In a research to determine the effects of genotype on egg performance, characteristics, Kamil et al. [65] reveled that hen genotype recorded considerable effects on some of the performance parameters and egg quality characteristics. Commercial white hens reported a higher egg production rate and produced eggs with better albumen and egg shell quality compared to the native brown strain. The authors noted that the brown strain yielded more cumulative eggs as a result of superior livability.

Olawumi and Dudusola [66] reported that Isa Brown (IB) was superior to Dominant Black (DB) in egg production and feed efficiency. This implies that IB genotype utilized feeds more efficiently, produced more eggs and appeared more profitable compared to DB genotype. In another study by the same author, Olawumi and Dudusola [67], the author revealed that breed has 
significant $(\mathrm{P}<0.01)$ effect on egg production. The evaluation of the performance of three breeds of commercial layers over a longterm period (15 months) showed that Isa Brown and Bovan Nera breeds are good, productive, efficient and viable in term of egg production, feed efficiency and mortality rate. They further stressed that the lower mean values reported for mortality rate also implies that the breeds are hardly and well adopted to the vegetation zone even though their production pattern showed some degrees of variability. They pointing out that any of the breeds (Isa Brown and Nera Black) can be used for commercial purposes without entertaining fears about their survival and production ability and tolerance to the prevailing hot weather.

Ershad [68] used hybrid and native hens to check their performance under various farm management system in a selected area in Bangladesh. The author reported that under intensive system hybrid layer rearing were better than native hen. The author also revealed that native hen showed moderate performance in terms of higher egg production, higher egg weight, body weight and lower mortality. Other parameters were higher in white shelled hybrid layers than Brown shelled hybrid layers under intensive system. Moreover, under scavenging system native hen was better also for the rural area of Bangladesh, because of low production cost, higher market price of eggs, live bird price and good profit.

\subsection{Housing}

Rapid intensification of the poultry industry since the 1930s and 1940s have culminated in mechanization and commercial production in laying cages. Keeping laying hens in cages has eradicated labour requirement and improve both barn hybrid and the health of the laying hens. However, this house regimen has been criticized [69] for producing a desolate environment to the laying hens. This criticism and a growing demand by consumers for eggs from laying hens not kept in cages [70] has resulted to the development of alternative and animal-friendly productive systems including freerange housing etc. However, negative effects of some of these alternative systems compared with the conventional cage system such as greater ammonia emissions [71], higher labour costs, and unhealthy working conditions [72-73] are now coming into play. Contemporary housing systems (alternative) for laying hens must be designed to balance the health and the welfare of the birds with consumer preferences, the requirements of the industry, and the influence on environment. Several housing systems for laying hens have observable influence on performance and production traits such as egg weight, egg breadth, egg length, egg shape index, egg shell weight, egg shell thickness, egg shell surface, egg yolk index, egg albumen weight, egg albumen index, Haugh units, egg shell index, body weight, and egg production $[2,6,8-12,45-$ 47, 49, 57, 74-78]. The experimental results of the effects of animal breeding and genetics scientists for improving the egg quality through the development of alternative and animal-friendly production systems (real or perceived) including free-run housing are summarized in Table 4 and in this section as follows:

Dikmen et al. [2] studied the impact of Conventional Cage (CC), Enriched Cage (EC), and Free-Range (FR) systems of layers of internal and external egg quality parameters of layers (Lohmann Brown). The result indicates that the highest Egg Weight (EW), York Weight (YW), Albumen Weight (AW), Shell Weight (SW), Albumen Index (AI), Yolk Index (YI), Haugh Unit (HU), (all P < 0.001), and the Shape Index (SI) values were found in Free-Range (FR) system eggs compared with Conventional-Cage (CC) and Enriched-Cage (EC) system eggs $(\mathrm{P}=0.045)$. The Shell Breaking Strength (SBS), shell thickness, Yolk Colour (YC), Shell Ratio of egg (SR), Yolk Ratio of eggs (YR), and Albumen Ratio of eggs (AR) were found similar in all housing systems. The researchers concluded that the eggs in the Free-Range (FR) system were better in overall quality than eggs from conventional-cage and enrichedcage systems.

Singh et al. [8] used conventional cages and floor pens to determine their influence on production performance and egg quality. The authors observed that housing systems significantly influ- enced body weight and mortality but not feed consumption or feed efficiency. In floor pens, Lohmann white and H\&N white hens laid most of their eggs in next boxes, whereas Lohmann Brown (LB) and cross hens laid half of their eggs on the floor. It was also recorded that eggs from cages hold lower Escherichia coli and coliform contamination than those from nest-boxes and the floor, and Escherichia coli contamination was greater for Lohmann Brown eggs than for Lohmann white. The authors finally suggest that genotype $\mathrm{x}$ environmental interactions should be considered when alternative housing systems are proposed.

Vits et al. [49] investigated the effects of three different furnished cage systems, Aviplus, Eurovent 625a and Eurovent 625A, on the different laying hens strains Lohmann Selected Leghorn (LSL) and Lohmann Brown (LB) for traits of production, egg quality, bone strength, claws length, and keel bone status. In the Aviplus system, egg production per average hen housed was higher than in Eurovent $625 \mathrm{a}$ and Eurovent $625 \mathrm{~A}$ systems, whereas shell thickness and density were lower. Humorous strength was equally higher in the Aviplus than in the Eurovent 625a system, whereas there was no observable significant difference in tibia strength among the three systems. The shortest claws were found in the Aviplus system, and the fewest keel bone deformities were reported in the Eurovent 625 a system. The authors revealed that the high standards of conventional cages for production and egg quality were met in furnished cages and that bone strength was significantly greater than in conventional cages. Claw shortening devices in furnished cages seemed satisfactory, in that claws were generally short. However, the occurrence of keel bone deformities which could be attributed to the intensive use of perches seemed to be a challenge of furnished cages.

In a study to evaluate the effects of cage density on laying hen performance and egg quality parameters by Saki et al. [9], eighty white leghorns were housed at four cage densities of 2000, 1000, 667 and $500 \mathrm{~cm}^{2}$ per hen, corresponding to $1,2,3$ and 4 hens per cage. The result revealed that the hens in the treatment having four hens per cage had significantly lower $(\mathrm{P}<0.05)$ body weight, egg weight, hen-day egg production, egg mass, feed intake, egg surface area, unit surface, egg shell weight, and yolk colour than hens in the treatment with 1 hen per cage. However, the hens in the treatment having four hens per cage had significantly higher $(\mathrm{P}<$ $0.05)$ feed consumption rate, egg specific gravity, eggshell ratio than hens in the treatment with 1 hen per cage. The authors suggest that white leghorn hens (Hy-Line W36) could be kept in cages at densities of 2,000 or $1,000 \mathrm{~cm}^{2}$ to improve egg quality parameters and performance.

A study was undertaken to determine what changes in egg quality characteristics occur during extended cold storage for commercially produced conventional cage, enriched colony cage, and cagefree aviary eggs by Jones et al. [12]. The result revealed that aviary and enriched eggs were significantly $(\mathrm{P}<0.05)$ heavier than conventional cage. Albumen height and Hough unit $(\mathrm{p}<0.05)$ were significantly greater for conventional cage than enriched eggs. Static compression shell strength was greatest $(p<0.05)$ for enriched eggs compared with aviary. No observable influence of the overall housing system was recorded for yolk measurements, shell dynamics stiffness, or whole egg total solids. Apart from the differences in the change of egg weight at 4 weeks of age, no significant difference in the rate of quality decline were found among the housing systems. The authors recommended from the result of their study that US egg quality standards should effectively define quality for commercially produced conventional cage, enriched colony cage, and cage-free aviary eggs.

Tumova et al. [7] evaluated the interactions in performance eggshell quality and tibia traits of two laying hen genotypes namely a commercial hybrid, Lohmann (LSL) and a traditional breed, the Czech Hen $(\mathrm{CH})$ housed in conventional cages and on litter. The result revealed that a significant interaction between genotype and housing was determined in egg weight. The heaviest eggs were laid by LSL hens housed in cages, and the lightest laid by Czech hen. Czech hens kept in cages produced the strongest shells $\left(4480 \mathrm{~g} / \mathrm{cm}^{2}\right)$, whereas the Czech hen in cages produced the weak- 
est shells $\left(3665 \mathrm{~g} / \mathrm{cm}^{2}\right)$. Layers housed on litter were significantly stronger tibias than hen housed in cages (485 vs 397N). Finally, the overall result revealed that the interaction between housing and genotype resulted in large difference in measurement of egg weight and egg shell quality.

Minelli et al. [75] compared the physio-chemical properties of egg laid either by hens reared according to the organic method or by caged hens kept in conventional system. The result indicates that the egg obtained from the organic system were higher (64.4 vs $66.2 \mathrm{~g}$ ) being yolk, albumen and eggshell weights statistically lower in comparison with those produced in conventional system. The yolk/albumen ratio resulted lower in the organic eggs ( 0.38 vs 0.39). The percentage of eggshell was not influenced by the hen rearing system whereas, the eggshell strength reported higher in the eggs produced in the conventional system $(3.265 \mathrm{vs} 3.135 \mathrm{~kg})$ The organic yolks were paler than the conventional ones.

Ojedapo [6] carried out a study to investigate the effects of cages vs deep litters housing systems on internal and external egg characteristics of commercial laying birds. The result revealed that there were significant $(\mathrm{P}<0.05)$ differences that exist between housing system and egg quality traits. A significantly higher value in deep litter than that of eggs from the cage birds for internal egg traits was observed only differed for yolk height that had higher value for yolk height in cage eggs. The author suggests that an appropriate housing system for a particular layer chickens should be considered to maximum egg quality traits.

In an experiment to determine the quality of table eggs produced in different housing systems by Dukic-Stojcic et al. [78], the quality of table eggs varied significantly depending on the different housing systems - conventional cage system, floor system with limited space and free range. The eggs produced in conventional cages reported greater mass and were cleaner than the egg produced in the floor systems. The best results for shell thickness were found in laying hens kept in the free range system.

Kamanli et al. [76] determine the influence of yellow incandescent bulb, white mini fluorescent lamp and white LEDs on some performance and egg quality traits in laying hens. The result revealed that the light sources had no effect on final body eight, albumen index and shape index but had observable influence on other traits. The results also indicated that though the cost of LED lamps was higher than that of other light sources, their energy consumption was lower. LED lamps did not have any negative impact on the production and egg quality of the laying hens.

Tumova et al. [47] studied the effect of housing (litter and conventional cages) quality characteristics employing Isa Brown, Hisex Brown and Moravia housed. The result indicates that the highest egg weight $(62.09 \mathrm{~g})$ was reported in Hisex-Brown genotype placed in cages. Eggshell strength was influenced by housing systems, genotype and egg collection time $(\mathrm{P}<0.049)$. It was higher in cage system compare with the litter counterpart, and lower in the Moravia genotype in comparison with Isa Brown and Hisex Brown.

The effect of housing systems (conventional cages and litter) and genotype (Czech hen and Lohmann) on egg quality was investigated by Svobodova et al. [46]. The result revealed that the housing system significantly $(\mathrm{P}<0.001)$ influenced egg weights. Higher values in Czech hen were observed in litter, on other hand in Lohmann compared to Czech hen. Shape index (76.46g vs $75.15 \mathrm{~g})$ and deformation $(0.31 \mathrm{~N}$ vs $0.29 \mathrm{~N})$ was higher in eggs from Czech hen compared to Lohmann.

Englmaierova et al.[77] studied the effects of laying hens housing system (conventional, enriched, cages, litter and aviaries) on laying performance and egg quality characteristics. The result indicates that the housing system significantly $(\mathrm{P}<0.001)$ influenced the performance characteristics. The highest egg production, lowest daily feed consumption, and feed conversion ratio were measured in conventional cages compared to litter and aviaries. Higher egg shell hens housed in enriched cages and aviaries laid eggs with a higher yolk index $(\mathrm{P}<0.001)$. On the whole, from the view point of egg safety, a more suitable substitute for conventional cages are enriched cages and aviaries than litter.

Ketta and Tumova [11] investigated the differences in the eggshell quality and the tibia measurements between Lohmann white and Czech hens housed in conventional cages and on litter system. The results indicate that the significant interactions between genotype and housing system were detected for the egg weight; the significantly heaviest eggs $(\mathrm{P}<0.001)$ were in Lohmann white low cages and the lightest weight in Czech hen in both housing systems. There was also significant interaction of genotype and housing system in the shell thickness, with the significantly thickest eggshells $(\mathrm{P}<0.003)$ in Lohmann white from litter system $(0.357 \mathrm{~mm})$ and the thinnest in Czech hen housed in cages $(0.310 \mathrm{~mm})$. The author concluded that genotypes can have a different reaction in the eggshell quality depending on housing system, and these interactions can be more important than individual factors.

Kanaman et al. [10] studied the physical characteristics and performance of laying hens caged in different tiers and environmental parameters of each tier. The results revealed that significant differences were observed between cage tiers with regard to temperature, relative humidity, and lighting intensity. The authors recommend that lighting intensity should be homogenous among all tiers in multlier caged houses.

Tumova et al. [45] employed three housing systems (conventional cages, enriched cages and litter) to investigate their effects on egg quality parameters with Isa Brown, Hisex Brown, Bovans brown and Moravia BSL. The results revealed a significant interaction between genotype and housing were found in egg weight $(\mathrm{P}<0.001)$, yolk and albumen weight $(\mathrm{P}<0.001)$ and yolk colour $(\mathrm{P}<0.001)$. Results of the study suggest that the ability of a strain to produce eggs of high quality in a particular housing system should be considered, even within brown strains.

\subsection{Age of laying hen}

One of the reasons producers keep their laying hens for only one cycle of production is as a result of most traits deteriorate with advancing age. Several studies observed such a decline in most of the traits that were evaluated in layers, with the exception of egg weight, which increased with age [23-25, 27]. Egg weight is an expression of the overall egg size, and optimum egg size, and optimum egg size varies according to the market in different countries [7]. The result of experiments on the potential influence of age on egg quality traits are summarized in Table 5 .

Ledur et al. [79] used three white leghorn strains, two-way crosses, and two commercial lines to evaluate the effects of aging on Heterosis $(\mathrm{H})$, reciprocal effects, and additive (A), Z-chromosome $(\mathrm{Z})$, and heterotic effects and their variances on egg quality traits during the first laying circle. The result indicates that egg weight heterosis increased in magnitude with age. The mean heterosis for both Haugh unit and albumen height was also influenced by age. The reciprocal effects were significant, on average, across periods for all traits were influenced by age. The age-related changes in additive, Z-chromosome, and heterotic effects varied significantly among strains, implying that differences by genetic group in response to aging for egg quality traits.

John-Jaja et al. [27] employed Bovan Neva Black laying hen to determine the influence of age on the egg quality traits. The results revealed that as the age of the laying hen and egg albumen weight increased, the regression coefficient of the traits revealed positive rate of change in traits from one age group to another.

Zita et al. [17] experimentally compared the effects of strain and age on egg quality characteristics in Isa Brown, Hisex Brown and Moravia BSL Brown-egg laying hens. The result indicates that egg quality characteristics were affected by age and genotype. Egg weight, yolk weight and percentage, Haugh units increased with the hens' age in all genotypes, but albumen and eggshell percentage decreased, eggshell thickness and strengths improved with age. 
Khawaja et al. [51] employed Fayoumi, Rhode, Island Red and their reciprocal crossbreed chickens to determine influence of age on the breeds. The result revealed that the breeds were affected as the age of the bird's advances $(\mathrm{P}<0.05)$.

John-Jaja et al. [26] used Bovan Neva Black laying chicken at 25, 51 and 72 weeks and overall mean ages of the bird to determine the influence of age on the egg length, egg breadth and egg shape index. The result revealed an apparent increase for egg length, egg breadth with the corresponding overall mean value with decrease egg shape index with its corresponding overall mean values.

Padhi et al. [23] employed Vananja male line (PDI) tiling 20 to 40 eggs at different ages in order to check the effect of the breed on egg quality in chicken. The result revealed that the age of the birds significantly affects different parameters of egg quality and as the age advance, at the end of cycle most of the quality parameters decreased in magnitude and the yolk content increases compared to the albumen content.

Molnar et al. [20] investigated the effect of age on egg quality traits between 60 and 80 weeks of age using a total of 1200 eggs collected on commercial layer farms in Flanders (Northern region of Belgium). The results revealed that flocks are depopulated before egg quality would start to cause economic problems. According to the authors, egg quality in general was still acceptable at the end of the laying cycle. This can be explained by the fact that producers set the date of depopulation based on the performance of the flock until $40-50$ weeks of age taking into account a decreasing egg quality and increasing heterogeneity from a certain age. But at the moment of depopulation there might be a potential for certain layer flocks to be kept longer.

Bozkurt et al. [48] carried out a research to determine the effects of genotype, cage density and position on the pullet performance of commercial layer chicks houses in cages from day 1 to 2 weeks and 2 to 4 weeks. The result revealed that the body weight, feed intake and feed conversion rate were affected by age between day 1 to 2 weeks and 2 to 4 weeks.

In a study to determine the performance of layer hybrids in some selected areas of Khulna region by Islam et al. [80]. The result revealed that with the increase of age, body weight of birds increased progressively and significantly $(\mathrm{P}<0.001)$ except 51 to 60 weeks' age group. The highest weight of birds was observed in $>60$ weeks' age group and lowest in up to 30 weeks' age group. The highest egg production percentage was observed in 31 to 40 weeks and lowest in up to 30 weeks' age group. Egg production was varied significantly $(\mathrm{P}<0.05)$ according to age of birds. Egg weight was increased progressively and significantly $(\mathrm{P}<0.001)$ with increasing age of birds except 51 to 60 -week age group.

Tumova and Goust [24] studied the interaction of hen production type, and temperature on laying pattern and egg quality. The result revealed that a significant interaction between type and age $(\mathrm{P}<$ 0.015 ) was evident in egg weight, but egg component proportions were dependent only on hen type. Egg shape index was significantly affected by age $(\mathrm{P}<0.004)$ and an interaction between type and age $(\mathrm{P}<0.001)$. Specific gravity declined with age $(\mathrm{P}<$ $0.035)$.

In a study to determine production performance of dual purpose crosses of two indigenous with two exotic chicken breeds in subtropical environment by Bekele et al. (2010). The result revealed that a significant age effect within crosses was found.

In a guest to determining the influence of egg quality of laying hens reared in organic and conventional systems by Minelli et al. [75], the authors observed that the albumen and egg weight increased significantly $(\mathrm{P}<0.01)$ with the hen aging whereas yolk weight and yolk/albumen ratio increased till 50 weeks at hen age and remain constant. The percentage of eggshell was not influenced by the hen rearing system while the eggshell breaking strength resulted higher in the egg obtained.

Padhi et al. [25] investigated Vanaraja male line (PDI) for different production and egg quality traits in India. The results indicate that the body weight at 20 and 40 weeks of age, egg production up to 40 weeks and egg weight at 32 weeks of age were low in magnitude.
In an experiment to evaluate the growth performance of local kei chickens and their $\mathrm{F}_{1}$-crosses with Rhode Island Red and Fayoumi breeds in watershed areas of Southern Ethiopia by Alew and Melesie [58]. The result indicates that at hatching, day old weight of the female was significantly $(\mathrm{P}<0.05)$ the same with the male counterpart but their magnitude varied. The same report was recorded during brooding (hatch -8 weeks), post-brooding $(9-20$ weeks) but at maturity ( $21-52$ weeks) the body weight and weight gain were significantly different $(\mathrm{P}<0.05)$ with higher magnitudes in male counterpart.

Singh et al. [8] investigated the influence of age on egg quality traits using four strains of laying hens kept in conventional cages and floor pens. The results indicate that at 20 weeks, body weight of hens in floor pen was significantly greater than that of hens in cages. The body weight of the hens increased with age to 40 weeks, but by 50 weeks, hens in cages lost weight and those in floor pens did not. Egg shell weight increased with age from week 20 to 40, but in cages, it decreased at week 50; in floor pens, no significant difference was found at week 40 and week 50 while egg weight and yolk weight were not significant at week 50. Albumen height for all strains (Lohmann white, Lohmann brown, $\mathrm{H} \& \mathrm{~N}$ white and cross breed) decreased as the age increased in both environments.

Dikmen et al. [2] studied the impact of different housing systems and age of layers on egg quality characteristics in Turkey. The results indicate that the egg weight, yolk weight, and albumen weight were increasing continuously during the laying period $(\mathrm{P}<$ 0.001 ). The shell weight increased at 40 weeks of age, then stayed stable until the end of the production period $(\mathrm{P}<0.001)$. The lowest egg shell breaking strengths were bound at $50 \%$ hen-day egg production age and 60 weeks of age $(\mathrm{P}<0.001)$. However, the highest shell thickness was observed at 40 weeks of age $(\mathrm{P}<0.001)$. The lowest shape index was found at $50 \%$ hen-day egg production age $(\mathrm{P}<0.001)$. The highest yolk index was observed oat $50 \%$ hen-day egg production age, and then it decreased with increased age until 40 weeks of age $(\mathrm{P}<0.001)$. The yolk colour score increased apparently with age until 50 weeks of age $(\mathrm{P}<0.001)$. The lowest Haugh unit were observed at 60 weeks of age $(\mathrm{P}<0.001)$. The albumen ratio decreased and yolk ratio increased with advancing age until 40 weeks of age. The lowest shell ratio was observed at 50 and 60 weeks of age $(\mathrm{P}<0.001)$.

Kamel [81] compared the growth and economic performance of Fayoumi, Rhode Island Red and other reciprocal crossbreed chickens in Egypt. The author discovered that Rhode Island Red showed the highest body weight, average daily gain and relative growth rate at $0-8,8-20,20-28$ weeks of age.

John-Jaja et al. [82] studied the influenced of age in egg weight and egg-shell weight in Ikenne, Nigeria. The results revealed that the values of egg quality traits apparently increased for egg weight and egg-shell weight at 25, 51 and 72 weeks of age.

\section{Concluding remarks}

The results of the study aimed at reviewing the influence of production factors such as breed (White Leghorn (WL), Isa Brown, Hisex Brown, Moravia, Czech Hen, Lohmann, Schijndelaar (S), Anucana (A), Rhode Islam Red (RIR), RIR x S, WL x S, WL x A, RIR x A, Broiler (100 500), Fayoum, Sonali indigenous, stain in white leghorn (IWH), IWI, IWK), Golden Montazal (M), 1/2 M1/2L $\left((1 / 2 \mathrm{M} 1 / 2 \mathrm{~L})^{2}\right)^{2}$, Bovan Brown Koekoek, white egg line, Brown egg line, Potcherstroom Koekoek, Black Olympia (ESA), H \& N Brown Nick (ESB), Local Type A (LTA), Local Type B (LTB), Lohmann white, Lohmann Brown, Rhode Islam Red (male and Plymouth Bared Rock (female) cross, Black Harco, Onagadori, Shower Brown, Nera Black, Lohmann selected leghorn, Atabey, Supernick Atek, Superbrown and Atak-S) that affect egg quality traits (but not limited to egg length, egg breadth, egg weight, egg shell weight, eggs shell thickness, egg shell strength, egg yolk weight, egg yolk index, egg albumen weight, egg albumen index, Haugh units, egg shell colour and egg shape index) confirmed 
significant differences in most breed/ strains/genotypes investigated as presented in Table $3-5$.

Owing to the numerous work reported by peers and researchers on effects of breed/genotype/strains on egg quality traits which is a major production factor in other to improve a particular breed/strain/genotype thereby culminating into high quality egg production parameter that is capable to increase animal edible protein so as to match the protein requirement of the teaming population. Thus, this promising production factor seems to be the most important factor in quantity maintenance as it deals with the additive genetic, genetic response and the inherent transmitting ability of parent traits from one generation to anther on a particular breed compared to other factors such as age, feed, management, disease control, collecting eggs and housing which concentrate on the environmental influence on the egg quality traits. This is achieved genetically by either comparing in order to discover the breed that records high transmitting ability from parent to offspring or more breeds or crossing one breed with another. To restate this, previous efforts to improve the breeds through genetic breeding is presented in the following:

Table 3: Breed, References and Egg Quality Parameters

\begin{tabular}{|c|c|c|c|c|c|c|c|c|c|c|c|c|c|c|c|}
\hline Breed & $\begin{array}{l}\begin{array}{l}\text { EL } \\
(\mathrm{cm})\end{array} \\
\end{array}$ & $\begin{array}{l}\begin{array}{l}\text { EB } \\
(\mathrm{cm})\end{array} \\
\end{array}$ & $\begin{array}{l}\begin{array}{l}\text { EW } \\
(\mathrm{g})\end{array} \\
\end{array}$ & $\begin{array}{l}\text { ESW } \\
(\mathrm{g})\end{array}$ & $\begin{array}{l}\begin{array}{l}\text { EST } \\
(\mathrm{mm})\end{array} \\
\end{array}$ & $\begin{array}{l}\begin{array}{l}\text { ESS } \\
\left(\mathrm{g} / \mathrm{cm}^{2}\right)\end{array} \\
\end{array}$ & $\begin{array}{l}\text { EYW } \\
(\mathrm{g})\end{array}$ & $\begin{array}{l}\text { EYI } \\
(\%)\end{array}$ & EYC & $\begin{array}{l}\text { EAW } \\
(\mathrm{g})\end{array}$ & $\begin{array}{l}\text { EAI } \\
(\%)\end{array}$ & $\mathrm{HU}$ & ESC & $\begin{array}{l}\text { ESI } \\
(\%)\end{array}$ & References \\
\hline Isa Brown & & & $61.16^{\mathrm{a}}$ & $6.38^{\mathrm{b}}$ & 0.37 & $4683^{b}$ & 16.58 & 44.92 & 8.61 & 36.62 & 7.82 & $83.19^{\mathrm{b}}$ & 34.21 & 76.1 & \multirow{3}{*}{$\begin{array}{l}\text { Tumova et al } \\
\text { [47] }\end{array}$} \\
\hline Hisex Brown & & & $62.09^{\mathrm{a}}$ & $6.29^{\mathrm{b}}$ & 0.39 & $4874^{\mathrm{b}}$ & 16.42 & 44.82 & 6.88 & 38.16 & 8.81 & $84.64^{\mathrm{a}}$ & 30.09 & 76.50 & \\
\hline Moravia & & & $58.91^{\mathrm{b}}$ & $5.66^{\mathrm{b}, \mathrm{c}}$ & 0.33 & $4597^{b}$ & 16.48 & 46.91 & 6.78 & 35.49 & 8.81 & $87.64^{\mathrm{a}}$ & 43.62 & 77.13 & \\
\hline Czech Hen & & & $49.5^{\mathrm{b}}$ & $4.72^{\mathrm{b}}$ & $0.316^{\mathrm{b}}$ & $4137^{\mathrm{b}}$ & & & & & & & & & \multirow{3}{*}{$\begin{array}{l}\text { Tumova et at } \\
\text { [7] } \\
\text { Lukanov et a] } \\
{[43]}\end{array}$} \\
\hline Lohmann & & & $60.4^{a}$ & $5.98^{\mathrm{a}}$ & $4353^{\mathrm{a}}$ & $4357^{\mathrm{a}}$ & & & & & & & & & \\
\hline Schijndelaar (S) & & & 45.90 & & & & & & & & & 65.13 & & 75.60 & \\
\hline Araucana (A) & & & 50.25 & & & & & & & & & 87.72 & & 78.98 & \\
\hline White Leghorn & & & 61.58 & & & & & & & & & 75.69 & & 76.47 & \\
\hline $\begin{array}{l}\text { Rhode Islam } \\
\text { Red (RIR) }\end{array}$ & & & 60.72 & & & & & & & & & 65.36 & & 77.64 & \\
\hline RIR $x S$ & & & 57.04 & & & & & & & & & 71.27 & & 77.01 & \\
\hline WL x S & & & 55.03 & & & & & & & & & 82.37 & & 75.56 & \\
\hline WL $x$ A & & & 56.15 & & & & & & & & & 81.87 & & 75.36 & \\
\hline RIR $\times \mathrm{A}$ & & & 57.92 & & & & & & & & & 72.39 & & 77.20 & \\
\hline $\begin{array}{l}\text { Broiler (100 - } \\
500)\end{array}$ & $5.69^{\mathrm{a}}$ & $4.22^{\mathrm{a}, \mathrm{b}}$ & $46.80^{\mathrm{b}}$ & $6.80^{\mathrm{c}}$ & & & $9.60^{b}$ & & & $30.40^{\mathrm{b}}$ & & & & & $\begin{array}{l}\text { Islam and Du } \\
\text { [83] }\end{array}$ \\
\hline Fayoum & $4.77^{\mathrm{c}}$ & $3.72^{\mathrm{c}}$ & $39.83^{\mathrm{d}}$ & $6.14^{\mathrm{c}}$ & & & $14.88^{\mathrm{a}}$ & & & $18.51^{\mathrm{c}}$ & & & & & \\
\hline $\begin{array}{l}\text { Rhode Islam } \\
\text { Red }\end{array}$ & $5.78^{\mathrm{a}}$ & $4.43^{\mathrm{a}}$ & $56.50^{\mathrm{a}}$ & $9.10^{\mathrm{d}}$ & & & $11.20^{\mathrm{b}}$ & & & $36.10^{\mathrm{a}}$ & & & & & \\
\hline Sonali & $5.46^{\mathrm{b}}$ & $4.12^{\mathrm{b}}$ & $43.80^{\mathrm{C}}$ & $7.90^{\mathrm{b}}$ & & & $16.40^{\mathrm{a}}$ & & & $19.50^{\mathrm{c}}$ & & & & & \\
\hline Ingenious & $4.83^{\mathrm{c}}$ & $3.71^{\mathrm{c}}$ & $40.04^{\mathrm{d}}$ & $6.41^{\mathrm{c}}$ & & & $14.65^{\mathrm{a}}$ & & & $18.92^{c}$ & & & & & \\
\hline IWU & & & $50.01^{b}$ & $4.32^{\mathrm{c}}$ & $0.336^{\mathrm{c}}$ & & $14.16^{\mathrm{c}}$ & & & $31.53^{\mathrm{b}}$ & & $72.99^{\mathrm{b}}$ & & & Sreenivas et \\
\hline IWI & & & $50.66^{\mathrm{b}}$ & $4.77^{\mathrm{b}}$ & $0.376^{\mathrm{a}}$ & & $14.70^{\mathrm{b}}$ & & & $31.19^{\mathrm{b}}$ & & $80.98^{\mathrm{a}}$ & & & al. [14] \\
\hline IWK & & & $53.89^{\mathrm{a}}$ & $5.12^{\mathrm{a}}$ & $0.362^{\mathrm{b}}$ & & $15.58^{\mathrm{a}}$ & & & $33.18^{\mathrm{a}}$ & & $65.38^{\mathrm{c}}$ & & & \\
\hline Control & & & $50.48^{\mathrm{b}}$ & $4.72^{\mathrm{b}}$ & $0.365^{\mathrm{c}}$ & & $14.84^{\mathrm{b}}$ & & & $30.92^{\mathrm{b}}$ & & $74.85^{\mathrm{b}}$ & & & \\
\hline $\begin{array}{l}\text { Golden Mon- } \\
\text { stsal (M) }\end{array}$ & & & $44.0^{\mathrm{a}}$ & $5.5^{\mathrm{d}}$ & $0.30^{\mathrm{a}}$ & & $14.4^{\mathrm{c}}$ & & & $24.2^{\mathrm{d}}$ & & $94.1^{\mathrm{a}}$ & & $78.1^{\mathrm{a}}$ & \\
\hline $\begin{array}{l}\text { White Leghorn } \\
\text { (L) }\end{array}$ & & & $45.7^{\mathrm{c}}$ & $5.5^{\mathrm{c}}$ & $0.27^{\mathrm{c}}$ & & $14.5^{\mathrm{b}, \mathrm{c}}$ & & & $25.6^{\mathrm{c}}$ & & $90.2^{\mathrm{b}}$ & & $76.2^{\mathrm{b}}$ & $\begin{array}{l}\text { Khalil et al. } \\
\text { [13] }\end{array}$ \\
\hline $1 / 2 M^{1 / 2 L}$ & & & $47.7^{\mathrm{b}}$ & $5.8^{\mathrm{b}}$ & $0.28^{\mathrm{b}}$ & & $14.7^{\mathrm{b}}$ & & & $27.2^{\mathrm{b}}$ & & $88.9^{\mathrm{b}}$ & & $76.4^{\mathrm{b}}$ & \\
\hline$\left(1 / 2 \mathrm{M}^{1 / 2 \mathrm{~L}}\right)^{2}$ & & & $44.4^{\mathrm{a}}$ & $6.0^{\mathrm{a}}$ & $0.27^{\mathrm{c}}$ & & $15.4^{\mathrm{a}}$ & & & $28.1^{\mathrm{a}}$ & & $78.6^{\mathrm{c}}$ & & $76.8^{\mathrm{ab}}$ & \\
\hline Isa Brown & & & $64.78^{\mathrm{a}}$ & & $0.34^{\mathrm{a}}$ & & 16.69 & & $6.13^{\mathrm{a}}$ & $37.23^{\mathrm{a}}$ & & $85.34^{\mathrm{b}}$ & & & $\begin{array}{l}\text { Tadesse et } \\
\text { al. [15] }\end{array}$ \\
\hline Bovan Brown & & & $63.46^{\mathrm{a}}$ & & $0.35^{\mathrm{a}}$ & & 15.39 & & $6.10^{\mathrm{a}}$ & 35.98 & & $87.45^{\mathrm{a}}$ & & & \\
\hline Koekoek & & & 42.79 & & 0.29 & & 14.54 & & $10.3^{\mathrm{a}}$ & 26.07 & & 78.88 & & & \\
\hline $\begin{array}{l}\text { White Egg } \\
\text { Line }\end{array}$ & & & 62.1 & & 0.36 & & & & & & & & & 74.0 & $\begin{array}{l}\text { Blanco et } \\
\text { al. [16] }\end{array}$ \\
\hline Brown Egg Line & & & 65.3 & & 0.35 & & & & & & & & & 78.0 & \\
\hline Isa Brown & & & $58.75^{\mathrm{a}}$ & & $0.31^{\mathrm{a}}$ & & 16.14 & & $9.74^{\mathrm{a}}$ & $33.37^{\mathrm{a}}$ & & 77.78 & & & Tadesse et \\
\hline Bovan Brown & & & $60.27^{\mathrm{b}}$ & & $0.33^{\mathrm{ab}}$ & & 15.97 & & $7.77^{\mathrm{ab}}$ & $34.54^{\mathrm{b}}$ & & 81.68 & & & al. [44] \\
\hline Isa Brown & & & 63.42 & 6.64 & 0.38 & 4525.23 & 17.81 & 43.63 & & 37.57 & 7.46 & 80.02 & & 75.09 & Zita et al. \\
\hline Hisex Brown & & & 64.12 & 6.38 & 0.36 & 4614.11 & 17.78 & 42.91 & & 38.49 & 7.11 & 83.46 & & 75.34 & [17] \\
\hline Moravia BSL & & & 65.30 & 5.88 & 0.32 & 4396.45 & 19.64 & 45.12 & & 38.25 & 8.40 & 85.96 & & 76.59 & \\
\hline
\end{tabular}

EW = Egg Weight, ESW= Egg shell weight, EST= Egg shell thickness, ESS=Egg shell strength ESC=Egg shell colour, EL = Egg Length, EB = Egg Breadth, ESI = Egg Shape Index, ESP= Egg shell percent, ESD= Egg shell density, BW = Body Weight, FE = Feed Efficiency, SSA = Shell Surface Area, $\mathrm{EV}=$ Egg Volume. 
Table 3: Breed, References and Egg Quality Parameters (Continues)

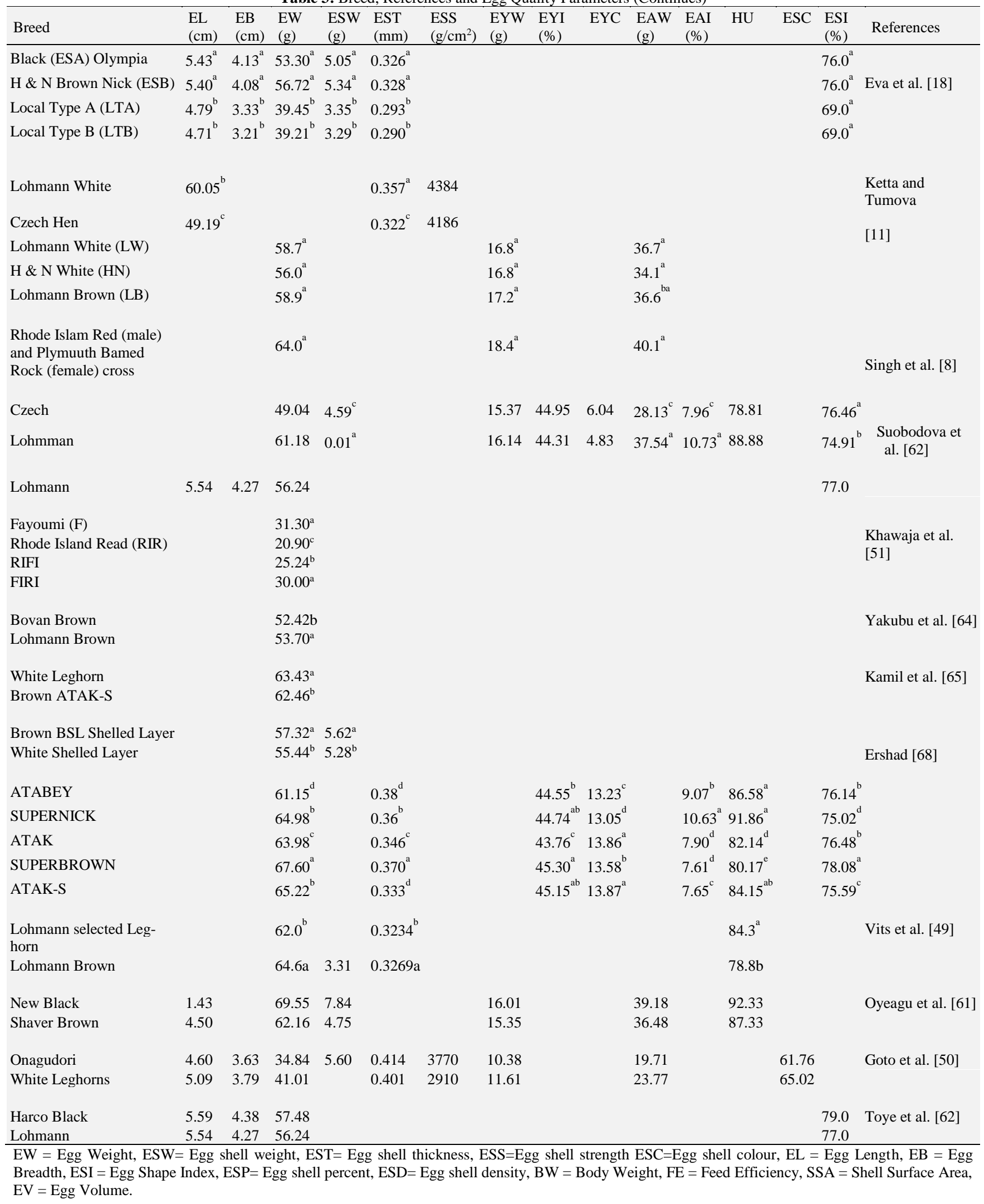


Table 4: Breed, Housing, References and Egg Quality Parameters

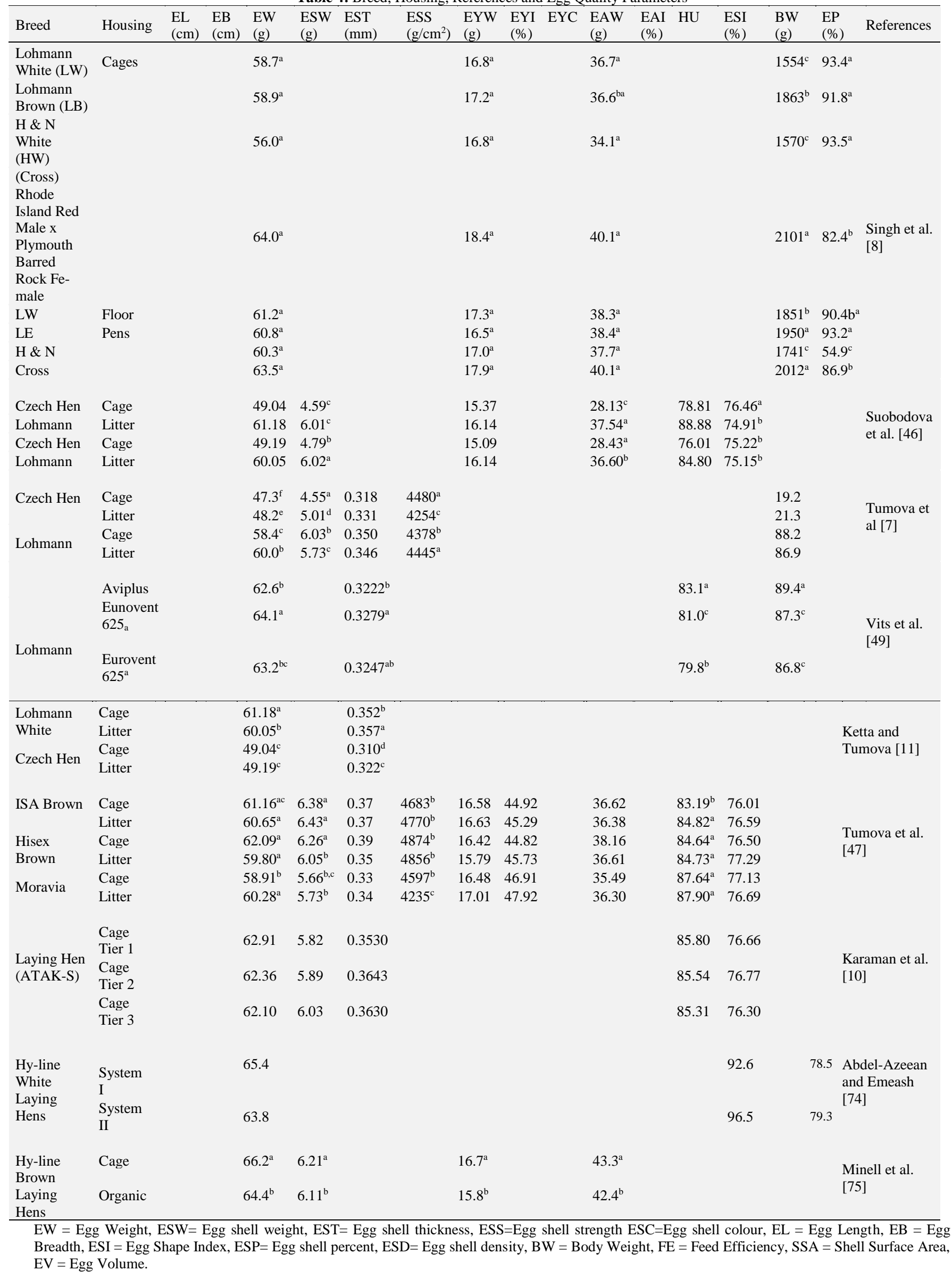


Table 4: Breed, Housing, References and Egg Quality Parameters (Continues)

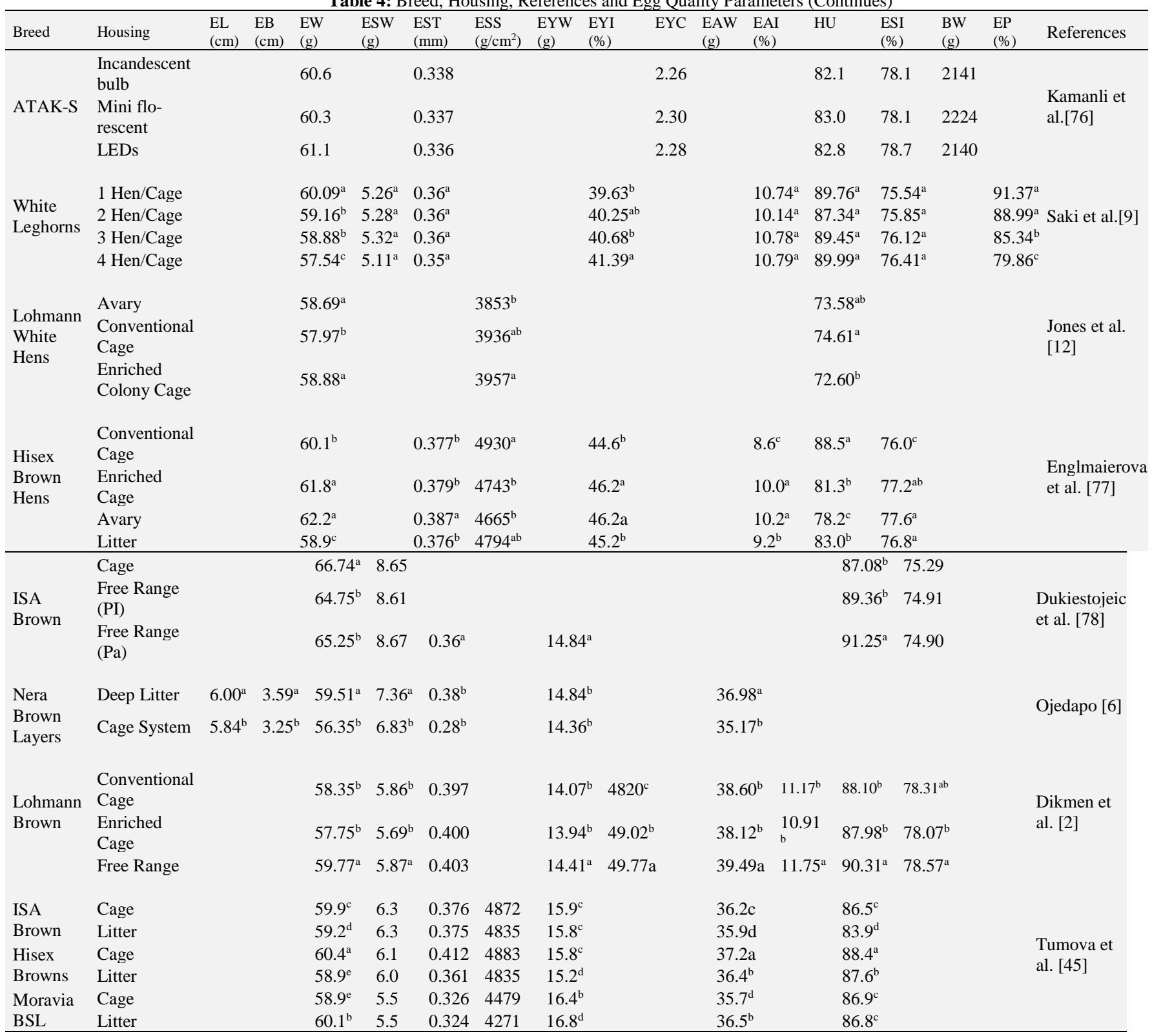

EW = Egg Weight, ESW= Egg shell weight, EST= Egg shell thickness, ESS=Egg shell strength ESC=Egg shell colour, EL = Egg Length, EB = Egg Breadth, ESI = Egg Shape Index, ESP= Egg shell percent, ESD= Egg shell density, BW = Body Weight, FE = Feed Efficiency, SSA = Shell Surface Area, $\mathrm{EV}=\mathrm{Egg}$ Volume.

\begin{tabular}{|c|c|c|c|c|c|c|c|c|c|c|c|c|c|c|c|c|c|}
\hline Breed & $\begin{array}{l}\text { Age } \\
\text { (Weeks) }\end{array}$ & $\begin{array}{l}\mathrm{EL} \\
(\mathrm{cm})\end{array}$ & $\begin{array}{l}\mathrm{EB} \\
(\mathrm{cm})\end{array}$ & $\begin{array}{l}\text { EW } \\
(\mathrm{g})\end{array}$ & $\begin{array}{l}\text { EBW } \\
(\mathrm{g})\end{array}$ & $\begin{array}{l}\text { ESW } \\
(\mathrm{g})\end{array}$ & $\begin{array}{l}\text { EST } \\
(\mathrm{mm})\end{array}$ & $\begin{array}{l}\text { EYW } \\
(\mathrm{g})\end{array}$ & $\begin{array}{l}\text { ESI } \\
(\%)\end{array}$ & $\mathrm{HU}$ & $\begin{array}{l}\text { EAW } \\
(\mathrm{g})\end{array}$ & $\begin{array}{l}\mathrm{EP} \\
(\%)\end{array}$ & $\mathrm{FE}$ & $\begin{array}{l}\text { Mortality } \\
(\%)\end{array}$ & $\begin{array}{l}\text { Feed } \\
\text { Intake } \\
(\mathrm{g} / \mathrm{bird} / \mathrm{d})\end{array}$ & $\begin{array}{l}\text { Month } \\
\text { Rate } \\
(\%)\end{array}$ & References \\
\hline \multirow{5}{*}{$\begin{array}{l}\text { Vanaraja } \\
\text { male line } \\
\text { (PDI) }\end{array}$} & 28 & & & $47.60^{c}$ & & 3.99 & & & 76.49 & 80.76 & 30.56 & & & & & & \multirow{5}{*}{$\begin{array}{l}\text { Padhi et al } \\
\text { [23] }\end{array}$} \\
\hline & 40 & & & $55.19^{\mathrm{b}}$ & & 4.48 & & & 75.29 & 81.38 & 33.53 & & & & & & \\
\hline & 52 & & & $61.74^{\mathrm{a}}$ & & 5.43 & & & 75.57 & 87.50 & 37.84 & & & & & & \\
\hline & 64 & & & $60.42^{\mathrm{a}}$ & & 5.01 & & & 76.00 & 78.43 & 36.01 & & & & & & \\
\hline & 72 & & & $61.07^{\mathrm{a}}$ & & 5.34 & & & 77.45 & 75.49 & 34.93 & & & & & & \\
\hline Lohmann & $22-29$ & & & 50.6 & & & & & 76.9 & 80.5 & & & & & & & \multirow{5}{*}{$\begin{array}{l}\text { Tumova } \\
\text { and Goust } \\
{[24]}\end{array}$} \\
\hline Brown & & & & & & & & & & & & & & & & & \\
\hline $\begin{array}{l}\text { Laying } \\
\text { Hen }\end{array}$ & $83-99$ & & & 68.6 & & & & & 74.7 & 69.4 & & & & & & & \\
\hline Cobb 500 & $36-43$ & & & 66.4 & & & & & 75.1 & 80.0 & & & & & & & \\
\hline Broiler & $64-71$ & & & 71.6 & & & & & 75.9 & 71.3 & & & & & & & \\
\hline Vanaraja & 40 & & & $56.39^{b}$ & & & 0.33 & & $76.80^{\mathrm{a}}$ & $73.46^{\mathrm{a}}$ & & & & & & & \multirow{3}{*}{$\begin{array}{l}\text { Padhi et } \\
\text { al.[25] }\end{array}$} \\
\hline male line & 52 & & & $59.96^{\mathrm{a}}$ & & & 0.34 & & $74.76^{\mathrm{b}}$ & $72.81^{\mathrm{ab}}$ & & & & & & & \\
\hline (PDI) & 60 & & & $61.04^{\mathrm{a}}$ & & & 0.33 & & $73.20^{\mathrm{b}}$ & $70.36^{\mathrm{b}}$ & & & & & & & \\
\hline Bovan & 25 & & & & & & & 13.14 & & & 35.52 & & & & & & \multirow{3}{*}{$\begin{array}{l}\text { John-Jaja } \\
\text { et al.[27] }\end{array}$} \\
\hline Near & 51 & & & & & & & 15.37 & & & 36.09 & & & & & & \\
\hline Black & 72 & & & & & & & 15.97 & & & 39.21 & & & & & & \\
\hline
\end{tabular}


Table 5: Breed, Age, References and Egg Quality Parameters (Continues)

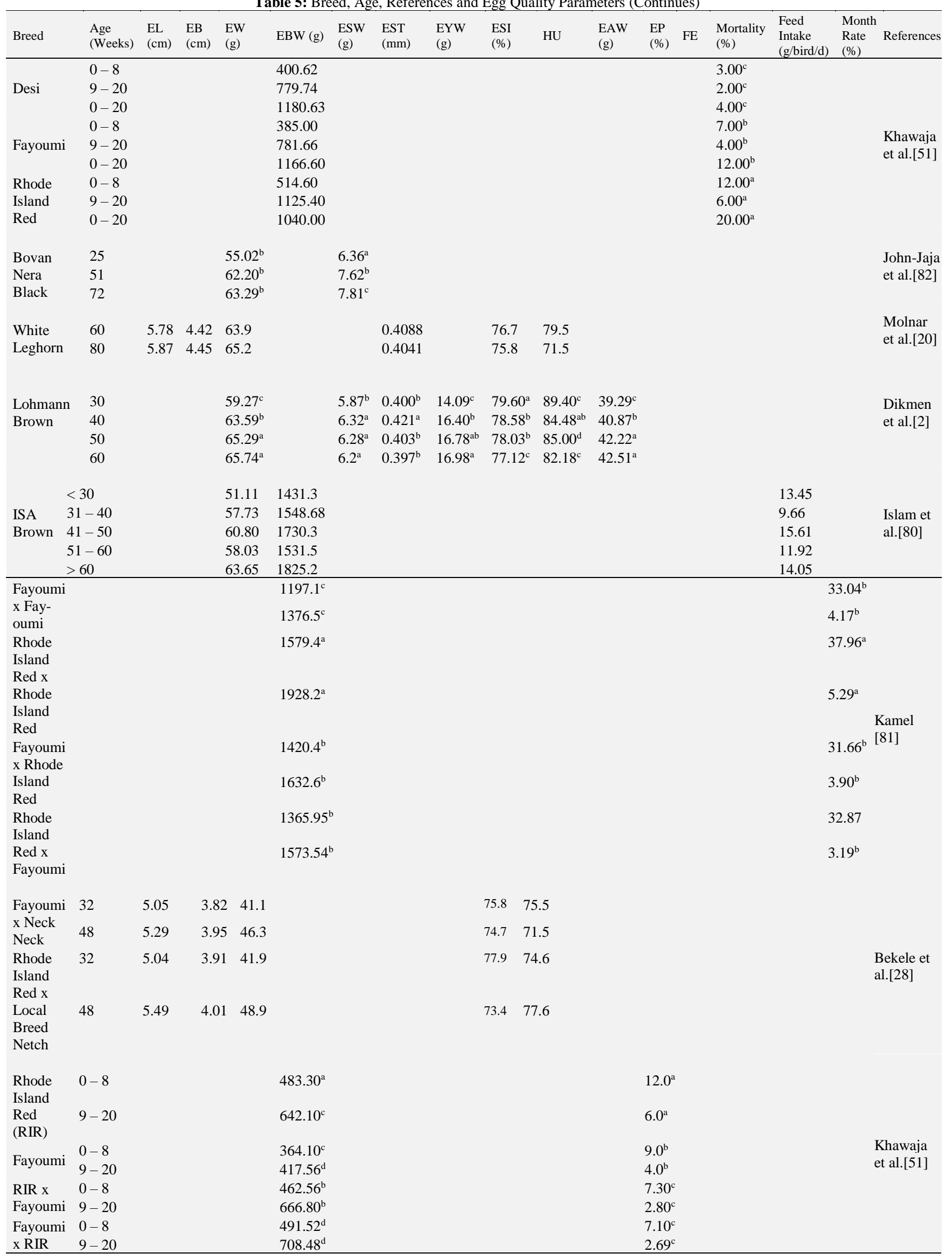


Table 5: Breed, Age, References and Egg Quality Parameters (Continues)

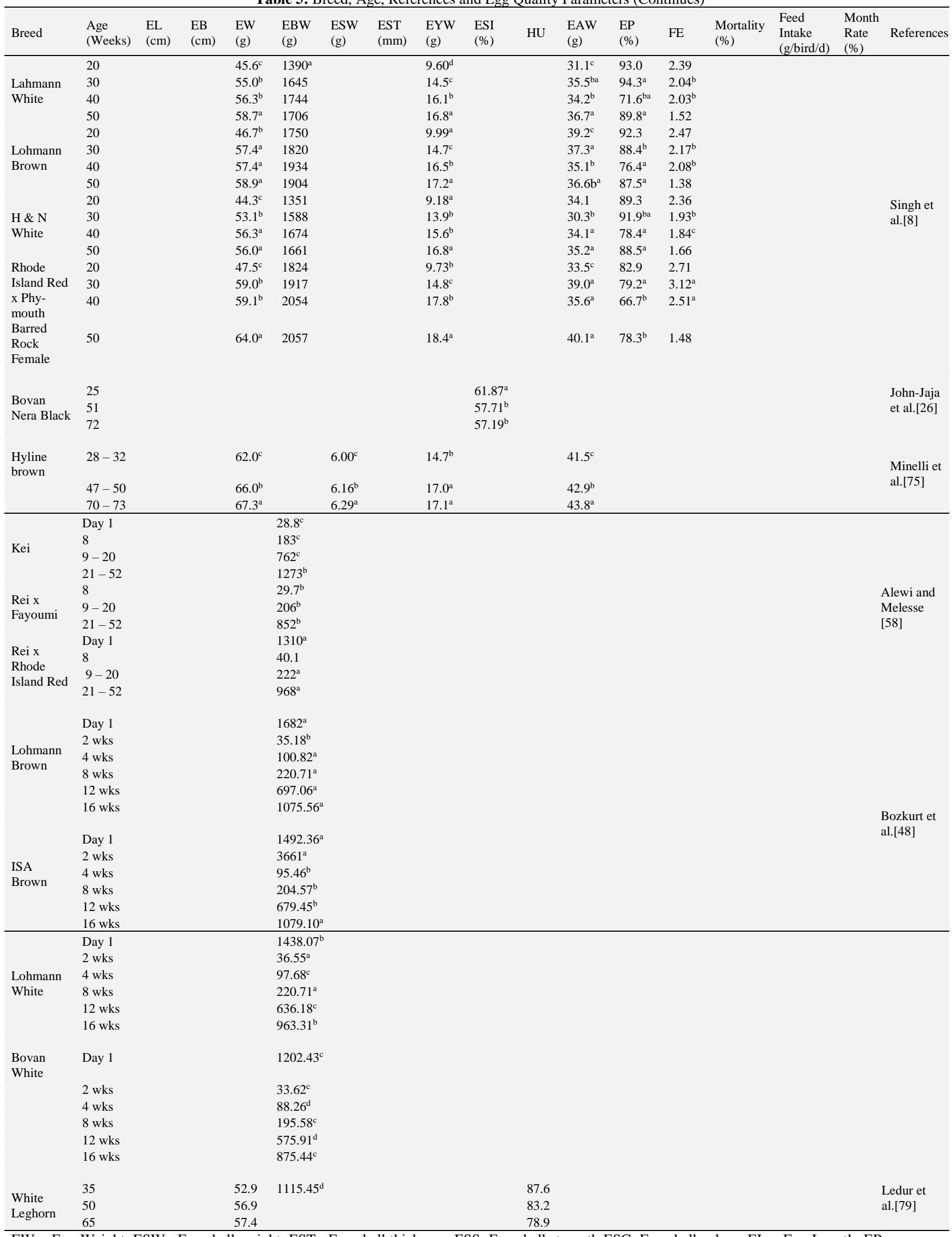

$\mathrm{EW}=$ Egg Weight, ESW= Egg shell weight, EST= Egg shell thickness, ESS=Egg shell strength ESC=Egg shell colour, EL = Egg Length, EP = egg performance, FE = Feed efficiency, EB = Egg Breadth, ESI = Egg Shape Index, ESP= Egg shell percent, ESD= Egg shell density, BW = Body Weight, FE = Feed Efficiency, SSA = Shell Surface Area, EV = Egg Volume. 


\section{References}

[1] FAO (2009). Food and agriculture organization of the United $\mathrm{Na}$ tions. The state of food insecurity in the world.

[2] Dikemen, B. H., Ipek, A., Sahan, U., Sozai, A. and Baycom, S. C. (2017). Impact of different housing systems and age of layers on egg quality characteristics. Turkish Journal of Veterinary and Animal Sciences, 41: 77-84. https://doi.org/10.3906/vet-1604-71.

[3] Hidalgo, A., Rossi, M., Chirici, F. \& Ratti, S. (2008). A market study on the quality characteristics of eggs from different housing systems. Food chemistry, 106: 1301-1308. https://doi.org/10.1016/j.foodchem.2007.07.019.

[4] Van, D. B. H., Parmentier, H. R. \& Kemp, B. (2004). Effects of housing system (outdoor vs cages) and age of laying hens on egg characteristics. British Poultry Science, 45: 745-752. https://doi.org/10.1080/00071660400014283.

[5] Dukie-Stojeie, M., Peric, L., Bjedov, S., Milosevic, N. (2009). The quality of table eggs produced in different housing systems. Biotchmology in Animal Husbandry, 25: 1103 - 1108.

[6] Ojedapo, L. O. (2013). Effect of two housing systems (Cages vs Deep litters) on external and internal egg characteristics of a commercial birds reared in derived Savannah zone of Nigeria. Transnational Journal of Science and Technology 3(7): 25-34.

[7] Tumova, E., Vickova, J., Charvatova, V., Drabek, O. and Tejnecky, V. (2016). Interactions of genotypes, housing and dietary calcium in layer performance, eggshell quality and tibia characteristics. South African Journal of Animal Sciences, 46(3): 285-293.

[8] Singh, B., Kumar, S. Kaur, N. and Yadar S. N. (2009). Evaluation of external and internal egg quality traits of hill focol reared under backyard system. Indian Journal of Poultry Science 41; 25-29.

[9] Saki, A. A., Zamani, P., Rahmati, M. and Mahmoudi, H. (2012). The effect of cage density on laying hen performance, egg quality and excretion minerals. Journal of Applied Poultry Resources, 21 467-475. https://doi.org/10.3382/japr.2010-00318.

[10] Karaman, S., Sekeroglu, A. and Duman, M. (2013). Physical characteristics and performance of laying hens caged in different tiers and environmental parameter of each tier. Transactions of the ASABE, 56(1): 321-328. https://doi.org/10.13031/2013.42588.

[11] Ketta, M. and Tumova, E. (2014). Differences in the eggshell quality and tibia strength in Lohmann white and Czech hen housed in cages and on litter. Acts sytotechology, 17(3): 75-78.

[12] Jones, D. K., Karcher, D. M. and Abdo, Z. (2014). Effect of a commercial housing system on egg quality during extended storage. Poultry Science, 93: 1282-1288. https://doi.org/10.3382/ps.201303631 .

[13] Khalil M. H., Iraqi, M. M. El-Atrouna M. M. (2013). Effects on egg quality traits of Crossing Egyptian Golden Montazah with white Leghom Chickens. Livestock Research for rural development 25(6): http://www.lnd.org/lord25/6/kha/ 25103.htm

[14] Sreenivas, D. Prakash, M. G., Mahender, M., Chatterjee, R. N. (2013). Genetic analysis of egg quality traits in white leghom chicken. Veterinary World; 6(5): 263-266.

[15] Tadesse, D., Esatn W. Girma, M., Dessie, T. (2015). Comparative study on some egg quality traits of exotic chicken in different production system in fact Shena, Ethiopic Africa Journal of Agricultural Research 10(9): 1016-1021. https://doi.org/10.5897/AJAR2014.9373.

[16] Blanco, A. E. Ould-Ali, D., Cuvero, D. and Schmutz, M. (2014) Genetic Parameters of egg quality traits on different pedigree layers with special focus on dynamic softness. Poultry Science; 93:24572463. https://doi.org/10.3382/ps.2014-04132.

[17] Zita, L., Tumova, E. and Stok, L. A. (2009). Effects of genotype age and htier interaction on egg quality in Brown-egg laying hens. $\begin{array}{llll}\text { Acta } & \text { Veterinary } & \text { BRNO, } & \text { 78: }\end{array}$ https://doi.org/10.2754/avb200978010085.

[18] Ewa, V. U., Otuma, M. O. Omeje, S. T. (2015). Interrelationships of external egg quality traits of four inbred live chicken stains Tropical Journal of Animal Science; 8(1):23-26.

[19] Van Sambeek, F. (2010). Longer production cycles from a genetic perceptive. Regress in layer genetics. Retrieved from http://www.isapoultry.com/2/media/files/ISA/information/Technica 1/\%20Bulletins/Breeding/Longer\%20production\%20cycles\%20fro $\mathrm{m} \% 20 \% 20$ genetic\%20perspective.ashe

[20] Molnar, A., Maertens, L., Ampe, B., Bnyse, J., Kempen, I., Zoons, J. and Delezie, F. (2016). Changes in egg quality traits during the last phase production: is there potential for an extended laying circle? British Poultry Science.

[21] Thiruvenkadan, A. K., Panneerselvam, S. \& Prabakarom, R. (2010). Layer breeding strategies: An overview. World's Poultry Science, 66: 477-502.

[22] Dunn, I. C. (2013). Long life layer: Genetic and physiological limitations to extend the laying period. 19th European symposium on Poultry Nutrition. pp. 124-129, Potsdam.

[23] Padhi, M. K., Chalterjee, R. N., Haunshi, S., Rajkumar, U. (2013). Effects of age on egg quality in chicken. Indian Journal of Poultry Science, 48(1): 122-125.

[24] Tumova, E., Gous, R. M. (2012). Interaction of hen production type, age and temperature on laying pattern and egg quality. Poultry Science, 91: 1269-1275. https://doi.org/10.3382/ps.2011-01951.

[25] Padhi, M. K., Chatterjee, R. N., Rajkumar, U., Haunshi, S., Nirunjan, M., Panda, A. K., Reddy, M. R. and Bhanja, S. K. (2015) Evaluation of Vanaraja male line (PDI) for different production and egg quality traits. Indian Journal of Animal Sciences, 85(6): 634637.

[26] John-Jaja, S. A., Abdullah, A. R. and Nwokolo, S. C. (2017). Genetic analysis of egg quality traits in Bovan Neva Black laying hen under sparse egg production period. Iranian Journal of Applied Animal Science, 7(1): 155-162.

[27] John-Joja, S. A., Udoh, U. H. and Nwokolo, S. A. (2016a). Repeatability estimates of egg weight and egg-shell weight under various production periods for Bovan Neva Black laying chicken. BeniSuet University Journal of Basic and Applied Sciences, 5: 389-394. https://doi.org/10.1016/j.bjbas.2016.11.001.

[28] Bekele, F., Adnoy, T., Gjoen, H. M., Kathle, J. and Abele, G. (2010). Production performance of dual purpose crosses of two indigenous with two exotic chicken breeds in sub-tropical environment. International Journal of Poultry Science 9(7): 702 - 710. https://doi.org/10.3923/ijps.2010.702.710.

[29] Buzala, M., Slomka, A., Janicki, B., Donczek, M. B. \& Zekanowska, E. (2017). Review: The mechanism of blood coagulation, its disorders and measurement in poultry. Livestock Science, 195:1-8. https://doi.org/10.1016/j.livsci.2016.11.009.

[30] Swiatkiewicz, S., Swiatkiewicz, M., Arczewska-Mosek, A. \& Jozefiak, D. (2014). Genetically modified feeds and then effect on the metabolic parameters of food producing animals: A review of recent studies.

[31] Ajayi, F. O. (2010). Nigerian indigenous chicken: A valuable genetic resources for meat and egg production. Asian Journal of Poultry Science, $\quad 4(4), \quad 164-172$ https://doi.org/10.3923/ajpsaj.2010.164.172.

[32] Buzala, M., Janicki, B., Czarneck, R. (2015). Consequences of different growth rates: A Review. Poultry Science, 94: 728-733. https://doi.org/10.3382/ps/pev015.

[33] Buzala, M. \& Janicki, B. (2016). Review: Effects of different growth rates in broilers and layer hens on some productive traits Poultry Science, 95: 2151-2159. https://doi.org/10.3382/ps/pew173.

[34] Chatterjee, R. N. Sharma, R. P., Niranjan, M. Reddy, B. N., and Mishra, A. (2006). Genetic Studies on egg quality traits in different white leghorn population. Indian Journal of Animal Genetic and Breeding 27:51-54.

[35] Devi, K. S. and Reddy, P. M. (2004). Effect of strain on physica egg quality characteristics in white leghoms layers. Indian Journal of Poultry Science 39:190-192.

[36] Devi, K. S. and Reddy, P. M. (2005). Genetic studies on certain economic traits in white leghom and cross-bred chicken. Indian Journal of Poultry Science. 40:56-58.

[37] Girinaj K. Naravanankutty, K. and Veeramani, P. (2008). Evaluation of reciprocal white leghom strain crosses for egg quality traits in deep litter system. Indian Journal of Poultry Science. 43:241242.

[38] Javalaxmi, P., Prasad, V. I. K. Murthy, S. R. N. and Reddy E. C. (2001). Inheritance of various egg quality traits in three strains of white leghorns. Indian Veterinary Journal 78; 820-823.

[39] Singh, R. Cheng, K. M. and Silversides, F. G. (2008). Production performance and egg quality of four strains of laying hens kept in conventional cages and floor pens. TBC Poultry Science, 1-9. https://doi.org/10.3382/ps.2008-00237.

[40] Curis, P. A., Gardner, F. A. and Mellor, D. B. (1995). A Composition of selected quality and compositional characteristics of brown and white shell eggs shell quality. Poultry Science, 64: $297-301$. https://doi.org/10.3382/ps.0640297. 
[41] Musa, S. Hasom D. and Umuts S. V. (2012). Determining the most effective variables for egg quality traits of five hen genotypes. International Journal of Agriculture and Biology. 14:235-240.

[42] Lukanov, H. Gencher, A. and Pavlov, A. (2015). Egg quality and shell colour characteristic of crosses between Araucana and Shcijndelaar with highly productive white leghom and Rhode Island Red Stain. Agricultural Science and Technology 7(3):366-371.

[43] Tadesse, D., Singh, H., Megistu, A. Esatu, W. and Dessie, T. (2013). Study on Productive performances and egg quality traits of exotic chickens under village production system in East Sherria, Ethiopia African Journal of Agricultural 8(13): 1123-1128. https://doi.org/10.5897/AJAR2013.6987.

[44] Tumova, E., Englmaierova, M., Ledvlnka, Z. and Chawatova, U. (2011). Interaction between housing system and genotype in relation to internal and external egg quality parameters. Czech Journal of Animal Science, 56(11): 490 - 498.

[45] Svobodova, J., Tumova, E. and Enghmaierova, M. (2014). The effect of housing system on egg quality of Lohmann white and Czech hen. Acta Cytotechu, 17(2): 44-46.

[46] Tumova, E., Skrivan, M., Englmaierova, M. and Zita, L. (2009). The effect of genotype, housing system and egg collection time on egg quality in egg type hens. Czech Journal of Animal Science, 54 (1): 17-23.

[47] Bozkurt, Z., Baynam, I., Turkunenoglu, I. and Aktepe, O. C. (2006). Effects of cage density and cage position on performance of commercial layer pullets from genotypes. Turkish Journal of Veterinary and Animal Science, 30: 17-28.

[48] Vits, A., Weitzenburger, D., Hamunn, T. and Disti, O. (2005). Production, egg quality, bone strength, claw length and keel bone deformities of laying hens housed in furnished cages with different group sizes. Poultry Science, 84: 1511-1519. https://doi.org/10.1093/ps/84.10.1511.

[49] Goto, T., Shiraishi, J., Bungo, T. and Tsudzuki, M. (2015). Characteristics of egg-related traits in the Onagadori (Japanese extremely long fowl) breed of chickens. Japan Poultry Science Association, 52: 81-87.

[50] Khawaja, T., Khan, S. H., Mukhtar, N. and Parveen, A. (2012). Comparative study of growth performance, meat quality and haematological parameters of Fayoumi, Rhode Island Red and their reciprocal crossbreed chickens. Italian Journal of Animal Science, 11(30): 311-216

[51] Farooq, M., Mian, M. A., Ali, M., Durroani, F. R., Asghar, A. and Muqarrab, A. K. (2001). Egg traits of Fayoumi birds under subtropical conditions. Sarhad Journal of Agriculture, 17: 141-145.

[52] Somu, Y. (2015). Comparative study of Giriroja and Desi birds under backyard system of rearing in farmers field. Veterinary Science $\begin{array}{lll}\text { Research } & \text { Journal, } & \text { 6(2): }\end{array}$ https://doi.org/10.15740/HAS/VSRJ/6.2/100-102.

[53] Semmarom, M., Sasidhar, P. V. K., Majumdar, S., Chander, Y. and Mahesh, T. H. (2008). Adoption behaviour of Girivoga backyard poultry by farmers in Kamataka. Indian Journal of Poultry Science, 43(3): 343-345.

[54] Neupane, D., Karki, M. and Shrestha, S. B. (2014). Intensive management of new Hampshire Girinoja chickens for generating premium cash income. Nepoil Journal of Science and Technology, 15(2): 23-28.

[55] Bharambe, V. Y. and Gand, P. K. (2012). Comparative performance of some improved poultry crossbreeds under Konkan region of India. Indian Journal of Hill Farm, 25(1): 48-52.

[56] Tadesse, G., Mengistu, A. and Tamir, B. A. (2016). Evaluation of the egg production performance in Bovns Browns and Koekoek chicken breeds under varied seasons and feeding regions in South Wollo zone, Ethiopia Global Veterinarian, 17(4): 318-324.

[57] Alewi, M. and Melesse, A. (2013). Evaluating the growth performance of local Kei chickens and their $F_{1}$ - crosses with Rhode Island Red and Fayoumi breeds in watershed areas of Guraghe administrative zone, Southern Ethiopia. Tropical and Subtropical Agroecosystems, 16: 39:50

[58] Hassen, H., Neser, F. W. C., VanMark-Koster, E. and Dekock, A. (2007). Village-based indigenous chicken production system in north-west Ethiopia. Tropical Animal Health and Production, 39: 189-197. https://doi.org/10.1007/s11250-007-9004-6.

[59] Taha, A. E. and AbdEl-Ghany, E. A. (2013). Improving production traits for El-salama and Manadarah chicken strains by crossing Iestimation of crossbreeding effects for growth production traits. Alexandria Journal of Veterinary Sciences, 39: 18-30.

[60] Oyeagu, C. E., Ani, A. O., Egbu, C. F., Udeh, F. U. and Omumuabuike, J. N. (2015). Comparative performance of Near Black and Sharer Brown hens fed self-compounded and commerce layers' diets. Asian Journal of Science and Technology, 6(01): 940-946.
[61] Toye, A. A., Sola-Ojo, F. E. and Ayorinde, K. L. (2012). Egg production, egg weight and egg mass repeatability and genetic gain from use of multiple time-spaced records in Black Harco and Lohmann Brown layers. Centrepoint journal, 18(2): 147-156.

[62] Tixier-Boichard, M., Jottrin, C., Govrichon, D. and Bordas, C. (2006). Improvement of yolk percentage by crossbreeding between a commercial Brown-egg layer and a local breed, the Fayoumi. In $8^{\text {th }}$ World Congress on genetics applied to livestock production. Belo Horizonte, Minas Gerais, Brasil, 13-18 August, 2006. p. 32.

[63] Yakubu, A., Saluko, A. E. and Ige, A. O. (2007). Effects of genotype and housing system on the laying performance of chickens in different seasons in the semi-humid tropics. International Journal of poultry $\quad$ Science, $\quad 6(6)$ : 434-439. https://doi.org/10.3923/ijps.2007.434.439.

[64] Kamil, K., Mehmet, B., Emine, N. H., Mustafa, C., Abdullah, U. C., Erol, B. and Fethiye, C. (2012). Effects of rearing systems on performance, egg characteristics and immune response in two layer hen genotype. The Asian-Australasian Journal of Animal Science, 25(4): 559-568. https://doi.org/10.5713/ajas.2011.11382.

[65] Oluwumi, S. O. and Dudusola, I. (2010). Effects of genotype and housing on reproductive performance of two strains of commercial layers in the dewed Savannah zone of Nigeria. Productive Agriculture and Technology, 6(1): 102-109.

[66] Olawumi, S. O., Dudusola, I. (2011). Assessment of long-term prorudction traits of three breed of exotic commercial layers in the dewed Savannah zone of Nigeria. Journal of Applied and Natural Science, 3(1): 20-24.

[67] Ershad, S. M. E. (2005). Performance of Hybrid layers and native hens under farmers' management in a selected area of Bangladesh. International Journal of Poultry Science, 4(4): 228-232. https://doi.org/10.3923/ijps.2005.228.232.

[68] Abdel-Azeem, N. M. and Emeash, H. H. (2016). Hyline-white behaviour laying performance and egg quality in two conventional caging systems with different densities. Asian Journal of Animal and Veterinary Advances, 11: 137-143. https://doi.org/10.3923/ajava.2016.137.143.

[69] Minelli, G., Sini, F., Folegatti, A., Meluzzi, A. and Framchini, A. (2007). Egg quality traits of laying hens reared in organic and conventional systems. Italian Journal of Animal Science, 6(1): 728730 .

[70] Kamanli, S., Dunus, I., Demir, S. and Tarim, B. (2015). Effect of different light sources on performance and egg quality traits in laying hens. European Poultry Science, 79: 1-7.

[71] Englmaierova, M., Tumova, E., Charvatova, V. and Skrivan, M. (2014). Effects of laying hens housing system on laying performance, egg quality characteristics, and egg microbial contamination. Czech journal of Animal Science, 59(8): 345-252.

[72] Ledur, M. C., Lilgedahl, L. E., Mcmillan, I., Asselstine, L. and Fairfull, R. W. (2002). Genetic effects of aging on egg quality trait in the first laying cycle of white leghorn strains and strain crosses. Poultry Science 81: 1439-1447.

[73] Islam, S. S., Paul, C. and Sarker, B. C. (2013). A comparative study of the performance of layer hydrides in some selected areas of Khulna region. Bangladesh Journal of Animal Science, 42(2): 114122.

[74] Kamel, E. R. (2016). Comparative study of growth and economic performance of Fayoumi, Rhode Island Red and their reciprocal crossbreed chickens. International Journal of Current Research, 8(5): 30163-20619.

[75] John-Jaja, S. A., Abdullah, A. R. and Nwokolo, S. A. (2016). Heritability estimates of external egg quality traits of exotic laying chickens under the influence of age variance in the tropics.

[76] Islam, M. S. and Dulta, R. K. (2010). Egg quality traits of indigenous, exotic and crossbred Chickens in Rajshahi Bangladesh Journal of Life Earth Science; 5:63-67. 